\title{
Lipid droplets: a classic organelle with new outfits
}

\author{
Toyoshi Fujimoto $\cdot$ Yuki Ohsaki $\cdot$ Jinglei Cheng $\cdot$ \\ Michitaka Suzuki $\cdot$ Yuki Shinohara
}

Accepted: 23 May 2008 / Published online: 11 June 2008

(C) Springer-Verlag 2008

\begin{abstract}
Lipid droplets are depots of neutral lipids that exist virtually in any kind of cell. Recent studies have revealed that the lipid droplet is not a mere lipid blob, but a major contributor not only to lipid homeostasis but also to diverse cellular functions. Because of the unique structure as well as the functional importance in relation to obesity, steatosis, and other prevailing diseases, the lipid droplet is now reborn as a brand new organelle, attracting interests from researchers of many disciplines.
\end{abstract}

Keywords Lipid droplet · Lipid ester · Phospholipid . Cholesterol $\cdot$ PAT protein $\cdot$ Caveolin

\section{Introduction}

Lipid droplets (LDs) are depots of neutral lipids that exist virtually in any kind of cell, ranging from bacteria to yeasts, plants, and higher mammals (Fig. 1a) (Murphy 2001). In the white adipocyte, an LD occupies the major portion of the cytoplasm and is easily observed by light microscopy. The adipocyte LD is the energy reservoir for the whole body, and the non-adipocyte LD has also been thought to store lipids, which are later used for $\beta$-oxidation, membrane biogenesis, protein lipidation, and so on. This understanding is basically correct, but recent studies have revealed that the LD has more diverse functions than previously thought. The LD is not only engaged in the functions directly related to intracellular lipid homeostasis, but might also be involved in

T. Fujimoto $(\varangle) \cdot$ Y. Ohsaki $\cdot$ J. Cheng $\cdot$ M. Suzuki $\cdot$ Y. Shinohara Department of Anatomy and Molecular Cell Biology, Graduate School of Medicine, Nagoya University,

65 Tsurumai, Showa, Nagoya 466-8550, Japan

e-mail: tfujimot@med.nagoya-u.ac.jp seemingly unrelated activities, including signaling, temporal protein storage, protein degradation, and so forth (Zweytick et al. 2000; Murphy 2001; Fujimoto and Ohsaki 2006; Martin and Parton 2006; Welte 2007). The molecular composition of the LD is being actively studied, but how those molecules collaborate to execute the diverse functions of the LD is still far from clear.

Some of the difficulties in the study of the LD originate from its unique architecture. In contrast to the vesicular organelles that have the aqueous content enclosed by a phospholipid bilayer membrane, the LD is made of a highly hydrophobic lipid ester core and the surface of a phospholipid monolayer (Fig. 2a) (Murphy and Vance 1999; Tauchi-Sato et al. 2002). That is, the LD and other organelles are similar in that the cytoplasmic surface is lined by a row of phospholipid headgroups, but, however, they do not have much in common. Due to this fundamental difference, various aspects of their structure and function, for example, growth and involution, import and export of lipids, binding and release of proteins, etc., may be governed by different mechanisms. The difference also requires critical re-evaluation of the techniques used for experimental analyses.

In this review article, we first overview the morphology and molecular composition of the LD and then discuss its possible biogenesis and involution processes, functions, and some pathological implications. Technical issues will be also treated in relation to the LD physiology.

\section{Morphology of the LD}

By transmission electron microscopy of conventional ultrathin sections, the LD appears as a spherical structure with homogenous content (Fig. 1b). The electron density of the LD content can vary depending on the method of sample 
preparation (Angermuller and Fahimi 1982). The LD surface lacks the unit membrane structure, and does not show clear delineation from the surrounding cytoplasm in most cases (Fig. 1b). Notably, membranes bound to ribosomes were observed inside the mast cell LD (Wan et al. 2007), and lamellar membranes were seen beside the macrophage LD (McGookey and Anderson 1983). Because lipids are not fixed by aldehydes, it is not always easy to preserve the lipidic structures, but these results suggest structural heterogeneities among LDs (Fig. 2b).

By freeze-fracture, convex, concave, and flat fracture planes are made with regards to the LD. The convex and concave fracture planes probably represent the interface between the surface phospholipid monolayer and the internal lipid ester core, and are devoid of intramembrane particles (Robenek et al. 2005). The LD sometimes shows multiple fracture planes of onion skin appearance (Baba et al. 1995; Tauchi-Sato et al. 2002), which may correspond to the multiple concentric lines seen in the isolated LD by cryoelectron microscopy (Tauchi-Sato et al. 2002). Their origin is not clear, but they might be generated during the sample preparation procedure due to the heterogeneous properties of the lipid esters in the LD core. For example, trioleylglycerol and tripalmitoylglycerol are the first and second most abundant triacylglycerols (TG) in the adipocyte $\mathrm{LD}$, but their melting temperatures are -4 and $65.5^{\circ} \mathrm{C}$, respectively (Kaye and Laby 1995). Due to this drastic difference, temperature changes during the experimental procedure may induce artificial segregation of the esters. How different lipid esters are organized in the LD in living cells is also intriguing because it may be related to the efficiency with which respective esters are metabolized.

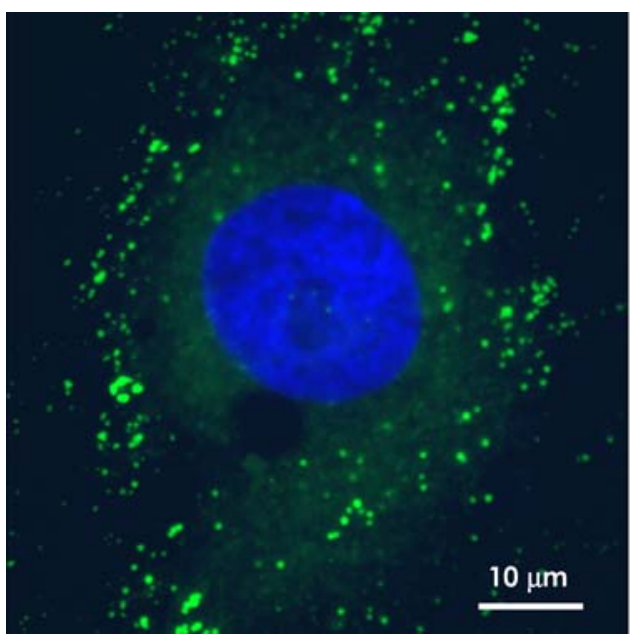

Fig. 1 The LD by light and electron microscopy. a Light microscopy. By labeling of rat $3 \mathrm{Y} 1$ fibroblasts loaded with oleic acid by BODIPY493/503 (green), LDs are observed as many small dots by fluorescence microscopy. The diameter of these dots is generally around $1 \mu \mathrm{m}$, and the smallest one is no less than $200-300 \mathrm{~nm}$ in diameter. The
Close structural association of LD and other organelles has been known for a long time (Ghadially 1997). The ER cistern is often apposed to, and sometimes wraps around, the LD (Novikoff et al. 1980; Blanchette-Mackie et al. 1995), and the relationship probably reflects the fact that the ER is the site of LD formation. The structural association appears to be stabilized by the cytoskeleton (Luckenbill and Cohen 1966), and the vimentin filament basket that forms around the LD of differentiating adipocytes (Franke et al. 1987) may also be related. In addition, the mitochondrion and peroxisome lie close to the LD occasionally (Novikoff et al. 1980; Stemberger et al. 1984; BlanchetteMackie et al. 1995; Schrader 2001), and a special amalgamation structure between the LD and peroxisome has been reported in Saccharomyces cerevisiae (Binns et al. 2006). Mitochondria and peroxisomes perform $\beta$-oxidation, and their close structural linkage with the LD should serve to effectively mobilize fatty acids from the lipid store. Besides these rather stable relationships, the LD may make transient contact with other organelles to supply lipids, as exemplified by a "kiss-and-run" encounter with the phagosome in the leukocyte (van Manen et al. 2005).

\section{Molecules in the LD}

Lipids

Besides TG, the LD core contains diacylglycerol (DG), cholesterol ester (CE), and other esters in various proportions (Zweytick et al. 2000; Murphy 2001). TG is the predominant lipid ester in white adipocytes, whereas the LD of

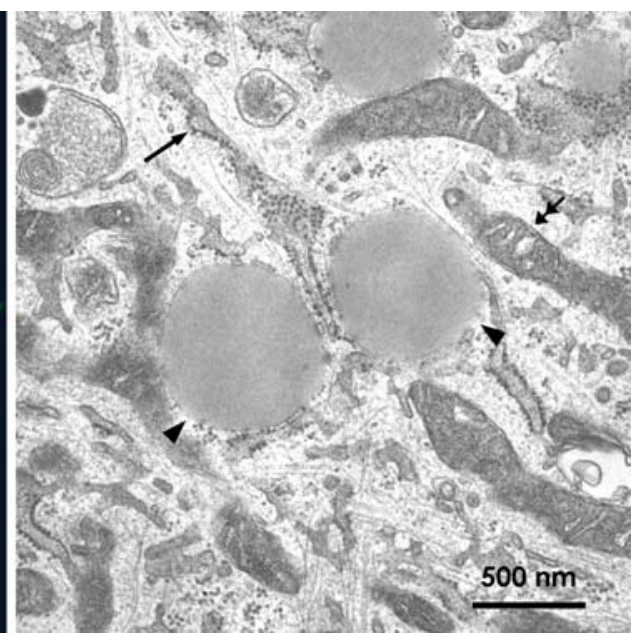

nucleus is stained by 4',6-diamino-2-phenylindole (blue). b Electron microscopy. In conventional ultrathin sections, the LD is observed as a structure with a homogenous content (arrowheads). In contrast with ER (arrow) and mitochondria (double arrows), the LD surface is not delimited by the unit membrane 
Fig. 2 Basic architecture of the LD. a Cryoelectron microscopy of the isolated $\mathrm{LD}$ and vesicle. Isolated LDs from HepG2 cells were rapidly frozen and observed by cryoelectron microscopy at the liquid helium temperature without fixation or staining. The LD surface was seen as a single electron-dense line (left figure; two adjacent LDs are seen), whereas the surface of a membrane vesicle was observed as two parallel lines (right figure). The electron density is solely derived from a row of phosphorus in the phospholipid head group. The result demonstrated that the LD surface is made of a phospholipid monolayer as depicted in the lower diagram. $\mathbf{b}$ The $\mathrm{LD}$ core is generally thought to consist of the lipid ester alone (left diagram), whereas presence of the ribosome-bound membrane as well as several proteins in the core has been reported in some cells (right diagram)
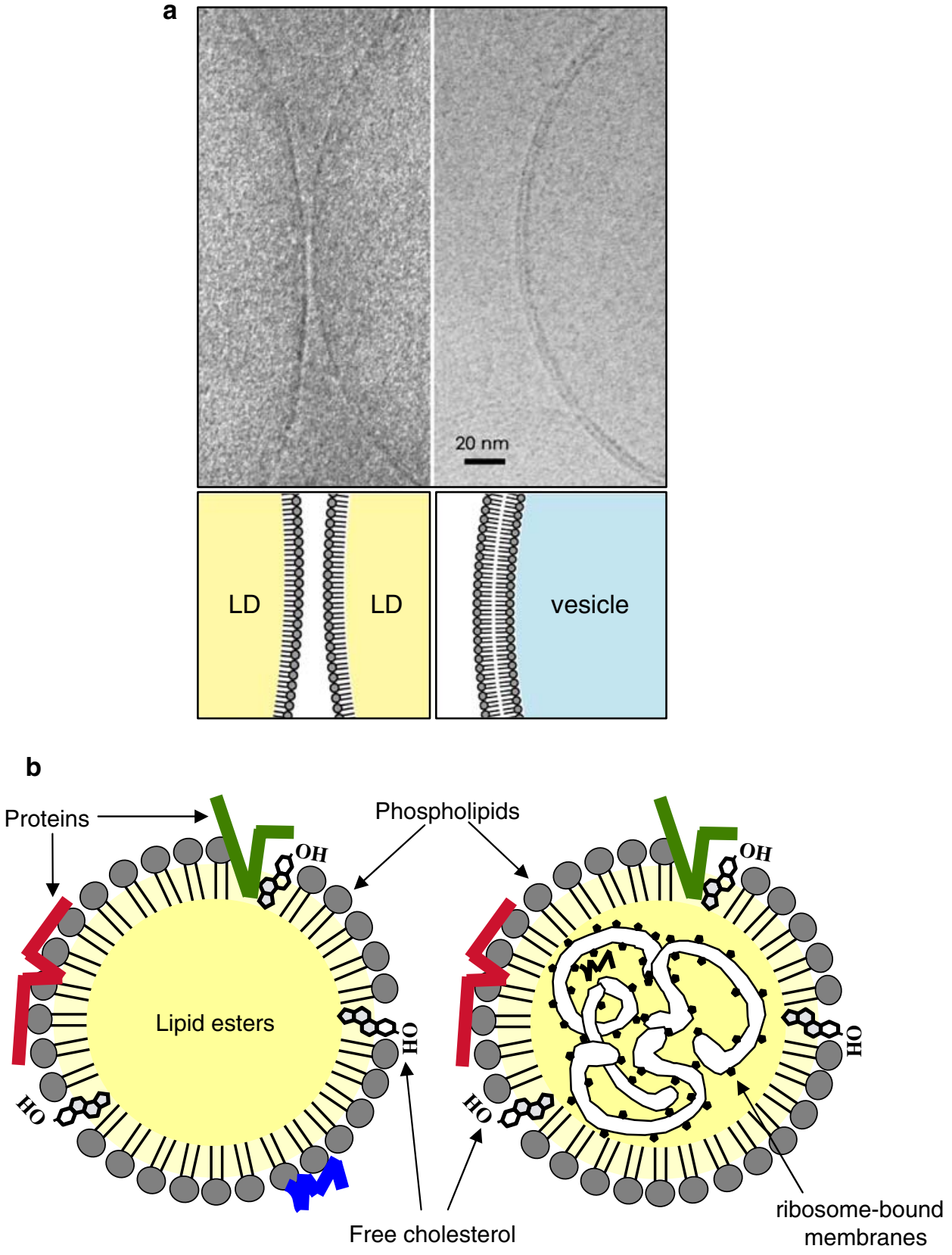

adrenocortical cells and ovarian and testicular interstitial cells are enriched with $\mathrm{CE}$ for steroid hormone synthesis. The retinyl ester exists abundantly in the LD of vitamin Astoring cells in the liver and several other organs. In most non-specialized cells, such as cultured fibroblasts, CE and TG appear to exist in various proportions.

The phospholipid composition of the LD is similar to that of the ER membrane in that phosphatidylcholine (PC), phosphatidylethanolamine (PE), and phosphatidylinositol (PI) are contained in this order (Leber et al. 1994). Lyso-PC and lyso-PE are also found in the LD (Tauchi-Sato et al. 2002). Peculiar characteristics of the LD are the abundance of unsaturated acyl chains in PC and lyso-PC (Tauchi-Sato et al. 2002) and the presence of the ether-linked form of PC and PE (Bartz et al. 2007). In addition to the phospholipids, a significant amount of free cholesterol (FC) is contained in the LD of white adipocytes, and the cell functions as a cholesterol sink for the whole body (Prattes et al. 2000). Intense filipin staining of adipocyte LD suggests that FC is contained in the surface phospholipid monolayer (Fig. 2b) (Prattes et al. 2000), although it may also exist in the LD core as speculated for lipoproteins (Hevonoja et al. 2000) and/or in the membrane adjacent to the LD (Ohsaki et al. 2008). Among total lipids of non-adipocyte LDs, the molar proportion of the FC is low due to the abundance of lipid esters, but the phospholipid-to-FC ratio in the surface layer has not been determined. Interestingly, an LD-associated protein, adipocyte differentiation-related protein (ADRP, 
also called adipophilin and ADFP), was recovered in the detergent-resistant membrane fraction when a low concentration of Triton X-100 was used (Tauchi-Sato et al. 2002), and this result might suggest that the LD surface may contain a domain similar to the membrane raft. The property that FC and lyso-PC form a tight stoichiometric complex may also influence the nature of the LD surface (Ramsammy and Brockerhoff 1982; Martin and Parton 2005). Although the information on the LD surface is still fragmentary, its unique molecular composition suggests that it was not made by random sampling of the ER membrane but, rather, derived from a special ER domain or formed by an elaborate mechanism.

\section{Proteins}

\section{PAT proteins}

Although the basic LD structure may be retained without an intervention of proteins, its formation, maintenance, modification, and involution should be regulated by a variety of proteins (Fig. 3). PAT proteins, named after perilipin, ADRP, and tail-interacting protein of $47 \mathrm{kDa}$ (TIP47), are the most well-known LD-associated proteins, and S3-12 and MLDP/OXPAT/PAT-1 also belong to this family (Londos et al. 2005; Brasaemle 2007). Perilipin is the first mammalian protein found as an LD-specific protein (Greenberg et al. 1991). Three isoforms, A, B, and C, generated by alternative splicing are known; the adipocyte expresses perilipin $\mathrm{A}$ and $\mathrm{B}$, whereas the steroidogenic cell has perilipin C. Perilipin functions as a shield against cytosolic lipases in the resting condition, but perilipin phosphorylated by protein kinase A forms a docking site for hormone-sensitive lipase (HSL) when lipolysis is activated by $\beta$-adrenergic stimulation (Sztalryd et al. 2003). Perilipin A also binds to an LD-associated protein, Comparative Gene Identification-58 (CGI-58, also called as Abhd5) (Yamaguchi et al. 2004), which is a coactivator of another cytosolic lipase, adipose triglyceride lipase (ATGL; also called as desnutrin, phospholipase A2 $\zeta$ ) (Lass et al. 2006). Perilipin A releases CGI-58 when phosphorylated by protein kinase A, but where, when, and how CGI-58 activates ATGL in the adipocyte are not established (Brasaemle 2007). Adipocytes cultured in a physiological condition harbor a major central perilipin-poor LD and small peripheral perilipin-rich LDs and lipolysis upon $\beta$-adrenergic stimulation occurs preferentially in the latter LDs (Moore et al. 2005). The result shows the functional importance of perilipin as well as the heterogeneity of LDs.

ADRP is expressed in a wide range of non-adipocytes (Brasaemle et al. 1997). During adipocyte differentiation, ADRP is replaced by perilipin although the ADRP's transcription continues (Brasaemle et al. 1997). In the perilipin-

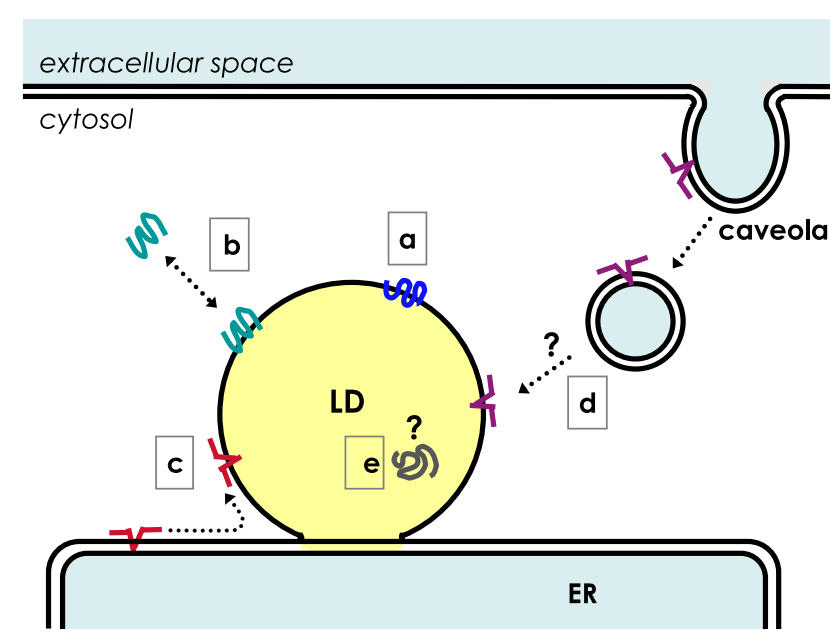

Fig. 3 Proteins are transported and localized in the LD by different mechanisms. Proteins in the LD may be classified into at least five categories according to their transport and localization mechanism. a Perilipin and ADRP are constitutively localized in the LD. b TIP47, S312, and MLDP/OXPAT/PAT-1 exchange between the LD and the cytosol. c Caveolins and oleosins translocate from the ER membrane to the LD by lateral diffusion. $\mathbf{d}$ Caveolin- 1 is endocytosed from caveolae and reaches the LD by an unknown mechanism. e The mechanism that causes some proteins to locate in the LD core is not known

null mouse, however, the adipocyte LD is coated by ADRP (Tansey et al. 2001). Likewise, TIP47, which exists largely as a soluble cytosolic protein, becomes the major non-adipocyte LD protein in the ADRP-null cell (Sztalryd et al. 2006). These results suggest the presence of a hierarchy in the PAT proteins in regards to LD binding, but the molecular basis for this is not clear.

ADRP has been shown to help preserve the cellular TG content, and this may result from its protective function against lipolysis (Listenberger et al. 2007). In the adipocyte, however, ADRP cannot substitute the perilipin's function as exemplified by the high basal lipolytic rate and low adiposity of the perilipin-null mouse (Tansey et al. 2001). An increase in TG in the microsome of the ADRP-null mouse liver compared to the normal counterpart suggested that the major function of ADRP is related to partitioning of TG between the LD and the membrane (Chang et al. 2006). The physiological role of TIP47 is even more elusive than ADRP. Because knockdown of TIP47 in the ADRP-null fibroblast decreased the number of LDs further (Sztalryd et al. 2006), TIP47 is also likely to have a protective function against lipolysis. TIP47 facilitates the recycling of the mannose-6-phosphate receptor from late endosomes to the trans-Golgi network by forming a ternary complex with the receptor and Rab9 (Carroll et al. 2001), but the question as to whether the function is related to its presence in the LD has not been addressed.

MLDP/OXPAT/PAT-1 also inhibits lipolysis in the LD and is present in oxidative tissues, such as cardiac muscle, 
red skeletal muscle, and the liver (Wolins et al. 2006b; Yamaguchi et al. 2006; Dalen et al. 2007). These tissues also express ADRP and TIP47, but how they cooperate in the LD is not known. Yet, a study has suggested that MLDP/OXPAT/PAT-1 may have a stronger protective effect against lipolysis than ADRP, and its expression promotes both $\beta$-oxidation and TG accumulation (Dalen et al. 2007). S3-12 protein is the most divergent member among PAT proteins and is expressed almost exclusively in the adipocyte (Miura et al. 2002). Its function may be related to lipid storage, but this remains to be clarified. For further discussion on the function of PAT proteins, readers can refer to recent excellent articles (Brasaemle 2007; Ducharme and Bickel 2008).

PAT proteins are thought to be translated in the free ribosome and are recruited to the LD post-translationally (Londos et al. 1999). Perilipin and ADRP are constitutively localized to the LD and rapidly degraded by proteasomes upon detachment (Fig. 3a), whereas S3-12, TIP47, and MLDP/OXPAT/PAT-1 are also stable as a soluble protein and translocated to the LD only under certain conditions (Fig. 3b) (Wolins et al. 2006a). Studies using deletion mutants of perilipin and ADRP did not specify any amino acid sequence as a targeting motif, but they did imply the engagement of several different hydrophobic domains redundantly (Garcia et al. 2003; McManaman et al. 2003; Nakamura and Fujimoto 2003; Targett-Adams et al. 2003). Acylation (Heid et al. 1996) and the 11-mer repeat that is also found in synucleins and apolipoproteins and predicted to form amphipathic helices (Bussell and Eliezer 2003) may be involved in the binding of PAT proteins to LDs. The 3D structure of TIP47 showed that its carboxy-terminal portion takes a structure similar to the four-helix bundle of apolipoprotein E, which mediates binding to lipoproteins (Hickenbottom et al. 2004). Although ADRP shows a significant sequence similarity with TIP47 in that region and is likely to adopt an analogous structure, only TIP47 can exist stably in a soluble form, probably by flexibly changing the shape of the putative hydrophobic pocket, whereas ADRP cannot do so and is degraded once it is released from the LD (Hickenbottom et al. 2004; Brasaemle 2007).

\section{Caveolins}

Caveolins, caveolin-1, 2, and 3, were discovered as scaffolding proteins to make the plasmalemmal caveolae, and were later found to localize in the LD under some circumstances (Fig. 3c, d) (Fujimoto et al. 2001; Ostermeyer et al. 2001; Pol et al. 2001; Martin and Parton 2005). Caveolin-1 binds free cholesterol (FC), glycolipids, and fatty acids (Fra et al. 1995; Murata et al. 1995; Trigatti et al. 1999), and is thought to be engaged in the intracellu- lar lipid transport (Martin and Parton 2005). Caveolin-1 distributes in the caveolae and Golgi membrane under normal culture conditions, but, when cells are loaded with lipids, caveolin- 1 is endocytosed by a dynamin- and protein kinase C-dependent pathway and translocates to the LD (Fig. 3d) (Sharma et al. 2004; Le Lay et al. 2006). How caveolin-1 translocates from the endocytic vesicular carrier to the LD has not been determined, but the caveolin-1dependent transport appears indispensable in maintaining the high FC content of the adipocyte LD (Le Lay et al. 2006). Caveolin-1-null mice show low adiposity but otherwise present a relatively mild phenotype under normal conditions (Drab et al. 2001; Razani et al. 2002). Upon partial hepatectomy, hepatocytes in normal mice accumulate a large number of LDs, whereas those of caveolin-1null mice do not show disturbances in cell cycle progression, with the animal failing to survive the injury unless supplemented with glucose (Fernandez et al. 2006). Because the serum lipid levels and the cellular lipid uptake appear normal in caveolin-1-null mice, the result suggests critical roles for caveolin-1 in the LD formation process in some circumstances.

Immunoelectron microscopy showed that caveolin-1 as well as several membrane and soluble proteins are located inside the LD (Fig. 3e) (Dvorak et al. 1992; Bozza et al. 1997; Robenek et al. 2005, 2006), a result that is not readily compatible with the general view that the LD core is a simple mass of lipid esters (Fig. 2b). Because caveolins are thought to reach the LD surface either by lateral diffusion from the ER membrane (Fig. 3c) or by the endocytic route (Fig. 3d) (Fujimoto et al. 2001; Ostermeyer et al. 2001, 2004; Pol et al. 2001; Le Lay et al. 2006), the presence of caveolin- 1 in the LD core is enigmatic. Combined with the observation of ribosome-bound membranes (Wan et al. 2007), however, the result suggests that LD core might contain some structures other than the lipid ester mass.

\section{Other proteins}

Besides the PAT proteins and caveolins, mass spectrometric analyses of isolated LDs identified a large number of proteins (Brasaemle et al. 2004; Fujimoto et al. 2004; Liu et al. 2004; Umlauf et al. 2004; Ozeki et al. 2005; Sato et al. 2006; Turro et al. 2006). The list contained many enzymes related to lipid metabolism, suggesting that some lipids are synthesized locally in the LD. The list also included proteins related to signaling, cytoskeletal proteins, and chaperones, but it was surprising that more than $10 \mathrm{Rab}$ proteins were detected. Among these, Rab18 is probably the only Rab that was confirmed to exist in the LD by microscopic methods (Martin et al. 2005; Ozeki et al. 2005). Rab18 is thought to be involved in the process of LD involution (Martin et al. 2005), and overexpression of 
Rab18 expels ADRP from the LD and induces close apposition of the LD and ER (Ozeki et al. 2005). Except for Rab18, presence of Rabs in the LD has not been confirmed microscopically even by overexpression of tagged proteins (Ozeki et al. 2005; Liu et al. 2007). We speculated that disruption of LDs upon homogenization is likely to expose the hydrophobic lipid ester, which may adhere irrelevant molecules non-specifically (Fujimoto and Ohsaki 2006). It may not be the sole cause of this discrepancy, but the above possibility needs to be excluded by microscopic methods before concluding that a protein in the LD fraction really exists in the LD in situ.

Several LD-associated proteins have been shown to influence the process of LD formation. Prp19p is known as a nuclear protein involved in DNA repair (Mahajan and Mitchell 2003), but is also located in the LD and appears to enhance LD biogenesis in the adipocyte by affecting the TG synthetic pathway (Cho et al. 2007). Fat-specific protein (FSP)27/Cidec is also highly expressed during adipogenesis and augments TG accumulation by down-regulating lipolysis (Puri et al. 2007). Seipin has been reported to localize at the LD-ER junction (Szymanski et al. 2007), and the absence of its yeast homolog induces aberrant LDs in yeast (Fei et al. 2008); the function of the protein has yet to be defined. Still other proteins that do not localize to the LD were shown to affect some aspects of the formation process, but the molecular mechanism is not necessarily clear, as discussed below.

\section{Other molecules in the LD}

Dvorak and colleagues have shown the presence of RNAs in the leukocyte LD (for a review, see Dvorak et al. 2003). In those cells, they also observed membrane-bound ribosomes inside the LD by electron microscopy, and hypothesized that some proteins are translated in the LD (Wan et al. 2007). A similar morphology has not been reported in the LD of other cell types, but RNA-binding proteins and ribosomal subunits were detected by proteomic studies (Cermelli et al. 2006; Sato et al. 2006; Wan et al. 2007), and inosine monophosphate dehydrogenase that binds to nucleic acids was also shown to localize in the LD (Whitehead et al. 2004). The meaning of these findings needs to be elucidated in future studies. Besides physiological molecules, some extraneous substances may concentrate in the LD. One example is polynuclear aromatic hydrocarbons derived from combustion (Murphy et al. 2008). They adsorb to the respiratory tract epithelium along with butadiene soot particles and then accumulate in the LD of the epithelial cell, alveolar macrophage, and adipocyte. The LD may serve as the reservoir of the toxicants and prolong their effect by releasing them slowly.
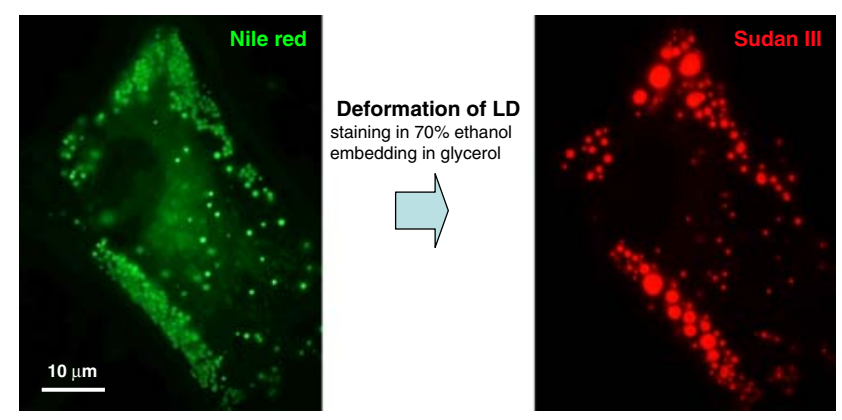

Fig. 4 Deformation of LD by staining and embedding procedures. Staining by alcoholic dyes and embedding cause gross deformation of LDs. In this example, human fibroblasts cultured with oleic acid were fixed by formaldehyde, stained by Nile Red dissolved in phosphate-buffered saline (PBS) and was photographed in PBS (left figure). The same cell was further stained by Sudan III dissolved in $70 \%$ ethanol, mounted in a medium containing about $25 \%(\mathrm{w} / \mathrm{v})$ glycerol, and photographed again (right figure). Although the overall distribution of the LD remained the same, LDs observed as a cluster of small LDs by Nile Red were grossly transformed to large LDs (often $>5 \mu \mathrm{m}$ in diameter) after the Sudan III staining, and the total area of the LD decreased by about $30-50 \%$. A similar deformation was observed by the Oil Red O staining

\section{Techniques to study the LD}

\section{Microscopic imaging}

The large LD of the white adipocyte is observed as a vacancy in histological paraffin sections stained by hematoxylin and eosin. This is because the lipid ester is not fixed by formalin and extracted by organic solvents during dehydration. The protein-rich cytoplasm around the LD is fixed and remains as a scaffold so that the overall shape of the LD can be recognized, but the lipid ester core is not retained. The inability of the aldehyde fixatives to fix lipids causes a similar problem when the LD is stained for fluorescence microscopy. Alcohols used to dissolve classical histological dyes (e.g., Sudan III and Oil Red O) induce artificial deformation of LDs (Fig. 4) (Fukumoto and Fujimoto 2002). Even when fluorescence dyes dissolved in aqueous buffers, such as BODIPY593/603 (Gocze and Freeman 1994) and Nile red (Greenspan et al. 1985), are used, glycerol in the specimen mounting causes a similar deformation. A similar artifact can occur in electron microscopy when aldehydes are used as the only fixative. Osmium tetroxide reacts with lipids and makes them insoluble (Riemersma 1968), but it is empirically known that most antigenicities are lost after osmium fixation.

LDs can be observed in live cells by several different techniques. GFP-tagged LD proteins have been used in many studies (e.g., Pol et al. 2001; Targett-Adams et al. 2003; Bostrom et al. 2005; Turro et al. 2006), but as the function of the proteins used for visualization is not always 
defined, their expression itself might modify the behavior of the LD in unpredictable ways. Fluorescence lipophilic dyes and lipids tagged with fluorescence groups might also have adverse effects on physiological processes (Greenspan et al. 1985; Gocze and Freeman 1994). More recently, polyene-lipids that behave similar to natural lipids became utilized as a probe and showed that they are incorporated into the pre-existing LDs as DG and TG, shortly after application (Kuerschner et al. 2008).

A new generation of microscopic techniques, such as third-harmonic generation microscopy (Debarre et al. 2006), coherence anti-stokes Raman spectroscopy (Nan et al. 2006), and Raman microspectroscopy (van Manen et al. 2005) as well as classical differential interference contrast microscopy (Nagayama et al. 2007), are non-invasive methods that can visualize LDs without any pretreatment or expression of exogenous proteins, and they should bring about non-biased information on the LD behavior in live cells. Yet, the space resolution of these techniques is no better than that of the fluorescence-based methods, and only LDs larger than 200-300 $\mathrm{nm}$ in diameter can be pursued (Fig. 1a).

The smallest LD in cells is smaller than that dimension. By electron microscopy of ultrathin sections, LDs as small as $50 \mathrm{~nm}$ in diameter can be observed under favorable conditions (Cheng JL, Fujimoto T, manuscript in preparation). The ${ }^{1} \mathrm{H}-\mathrm{NMR}$ analysis showed that the lipid ester in living cells exists as a globule of about $25 \mathrm{~nm}$ in diameter (Lacey et al. 1999), although the origin of the signal has been debated (Mountford and Wright 1988; Hakumaki and Kauppinen 2000). Finally, in an in vitro model system, atomic force microscopy visualized small wax ester globules formed on mica sheets, whose average size was $50 \mathrm{~nm}$ in diameter and $15 \mathrm{~nm}$ in height (Waltermann and Steinbuchel 2005). These results suggest that the LD in living cells could be far smaller than the resolution limit of light microscopy. Those small "invisible" LDs might contribute to the growth and involution of larger "visible" LDs as conjectured below.

\section{Biochemical analysis}

Biochemical purification of LDs has been performed by density-gradient ultracentrifugation (Leber et al. 1994; Yu et al. 2000). After disruption of cells and tissues, isolated LDs can be collected in a reasonable purity because the low density of lipid esters makes LDs to float to the top surface of the gradient, whereas soluble proteins and membranes remain in fractions of higher densities. Markers of other organelles are scarcely detected in the LD fraction, but some ER proteins are occasionally included. The latter result may reflect the real presence of the ER components in the LD itself, but is not always easy to exclude an artifi- cial inclusion of adjacent structures in the isolated preparation. For example, the yeast vacuole adheres to LDs in situ and is recovered in the LD fraction unless an additional procedure to separate them is carried out (Leber et al. 1994).

Another concern for LD isolation by density-gradient centrifugation is that small LDs may be recovered in the top-floating fraction only with a limited efficiency compared to larger LDs. This is likely because lipoproteins also have widely variable densities, from $\sim 0.96 \mathrm{~g} / \mathrm{ml}$ for chylomicron to $\sim 1.063 \mathrm{~g} / \mathrm{ml}$ for high density lipoprotein. The lipoproteins are thought to have a common basic structure made of the lipid ester core and a phospholipid monolayer (Hevonoja et al. 2000), but the phospholipid-to-lipid ester ratio should be larger as the particle size is smaller, which may result in the varied densities. In fact, the LD of nonadipocytes is recovered in the top-floating fraction only with a low efficiency if the cells are not cultured with fatty acids (Listenberger et al. 2007). The results suggest that the LD preparation obtained by centrifugation may be biased toward relatively large LDs and may not represent LDs smaller than a certain limit.

\section{The biogenesis of the $\mathrm{LD}$}

\section{Birth of the LD}

The mechanism by which the LD is produced in the cell has attracted much interest, and several different models have been proposed (Fig. 5) (Zweytick et al. 2000; Wanner et al. 1981; Waltermann et al. 2005; Ploegh 2007; Murphy and Vance 1999). The prevailing hypothesis supposes the following sequence of events for LD formation: the newly synthesized lipid ester is deposited in the membrane, and, as the amount exceeds the molar proportion that can be assimilated in the phospholipid bilayer, the lipid ester begins to segregate between the two membrane leaflets by phase separation. As such, the lipid ester mass gradually bulges toward the cytoplasm and finally separates from the mother membrane as a nascent LD (Fig. 5a). This hypothesis gives a reasonable explanation on how the lipid ester globule covered by a phospholipid monolayer is formed from a phospholipid bilayer. Experimental evidence for each step, however, has been rather scarce.

The enzymes that catalyze the last step of the TG and CE synthesis in mammalian cells are two isoforms of acylcoenzyme A:diacylglycerol acyltransferases (DGAT1 and DGAT2) and two isoforms of acyl-coenzyme A:cholesterol acyltransferases (ACAT1 and ACAT2), respectively, and some, if not all, were shown to exist in the ER (Smith et al. 2000; Chang et al. 2001; Stone et al. 2006). In contrast, Dgalp, the yeast homolog of mammalian DGAT2, distributes 


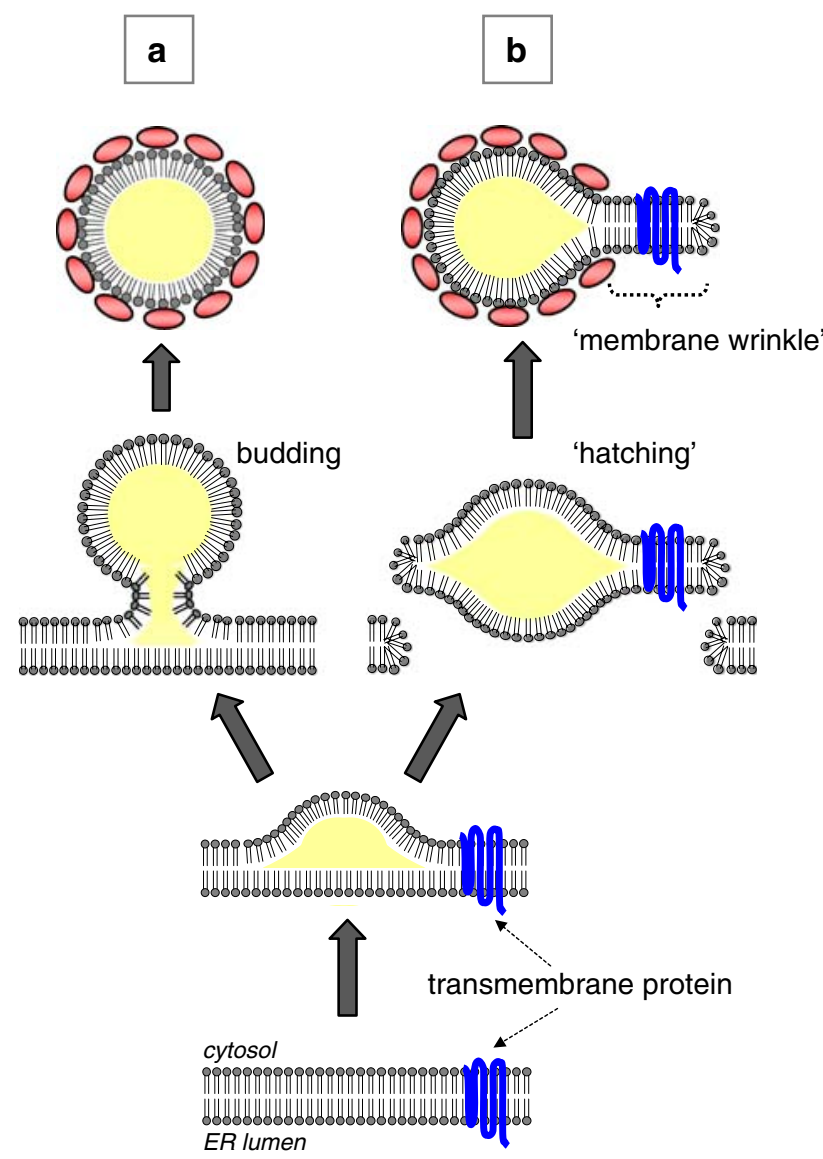

Fig. 5 Possible mechanisms of the LD birth. The lipid ester accumulating in the ER membrane is assumed to leave there either by budding (a) or by "hatching" (b). The surface phospholipid of the nascent LD should be derived from the cytoplasmic leaflet of the ER membrane in the budding process, whereas it comes from both the leaflets in the hatching process. For budding, the lipid ester mass needs to bulge toward the cytoplasm and to be constricted for fission. For hatching, the ER membrane needs to be disrupted on both the sides of the lipid ester mass

mainly in the LD (Sorger and Daum 2002), and overexpressed DGAT2 was also found around LD in mammalian culture cells (Kuerschner et al. 2008). The results suggest that some TG may be synthesized in the LD or in an ER subcompartment adjacent to the LD. Nonetheless, because the major synthetic activities for TG and CE are recovered in the microsome fraction (Lehner and Kuksis 1996; Buhman et al. 2000), the ER membrane is a probable site where a new LD begins to form.

If the newly produced lipid ester accumulates between the two membrane leaflets, it is expected to be observed as a globule in the ER membrane, and the cytoplasmic and lumenal membrane leaflets of the ER should be continuous with the LD surface. Yet, a structure corresponding to the globule has hardly been observed. A notable example is a direct continuity between an LD and a thick trilaminar appendage in the cotyledon of some plants (Wanner and Theimer 1978). Although the appendage may be derived from the ER membrane, it is far thicker than the usual membrane, that is, $20-23 \mathrm{~nm}$, and the identity is not defined clearly. In a freeze-fracture study, a continuity of the cytoplasmic leaflet of the ER membrane to a putative LD surface was reported, but the latter structure may not be the usual LD because the fractured concave plane contained many intramembrane particles (Blanchette-Mackie et al. 1995). We recently identified a structure that topologically corresponds to the lipid ester globule between the two membrane leaflets of the ER in cultured hepatocytes (Fig. 6) (Ohsaki et al. 2008). The structure was induced by anomalous binding of lipidated apolipoprotein B to the ER membrane, and probably corresponds to the LD arrested at an intermediate stage of formation.

However, a similar structure has never been observed in normal cells, probably because the nascent LD separates from the ER before reaching a detectable size. The results of ${ }^{1} \mathrm{H}-\mathrm{NMR}$ (Lacey et al. 1999; Hakumaki and Kauppinen 2000) and atomic force microscopy (Waltermann and Steinbuchel 2005), as well as the thickness of the ER membrane, that is, 5-7 nm, suggest that the nascent LD may be very small and may be difficult to capture even by electron microscopy. In other words, the LD observed by conventional methods may only be made after the "growth" of the smaller nascent LD.

The separation of the nascent LD from the ER membrane is generally presumed to occur by budding and fission so that the surface of the LD originates from the cytoplasmic leaflet of the ER (Fig. 5a). The mechanism of the vesicular budding have been characterized [for reviews, see (McMahon and Mills 2004; Praefcke and McMahon 2004; Corda et al. 2006)], but a completely different mechanism may be needed for the LD because the content and surface of the LD have vastly different properties from that of vesicles. An alternative mechanism for LD formation was proposed recently: the nascent LD is hypothesized to form by "hatching", in which the lipid ester globule detaches from the ER together with the two membrane leaflets (Fig. 5b) (Ploegh 2007). By this scenario, a transient pore is made in the membrane, and this may be important for misfolded proteins in the ER lumen to be translocated to the cytoplasm for proteasomal degradation. This hypothesis can explain the presence of ER proteins, especially for some transmembrane ones, in the LD (Dvorak et al. 1992; Bozza et al. 1997; Robenek et al. 2004, 2005) because the intact membrane fragment can remain attached to the $\mathrm{LD}$ as a wrinkle.

\section{Growth of the LD}

There are several possible ways for the pre-existing LD to grow larger (Fig. 7). As demonstrated by live imaging, mutual fusion of LDs is one probable mechanism (Fig. 7a) 
Fig. 6 The LD arrested in the ER membrane. a The LDs harboring ADRP (red) on a hemisphere and apolipoprotein B-100 (green; arrowheads) on the complementary hemisphere. This structure was named as "ApoB-crescent". The ApoBcrescent increased drastically when degradation of apolipoprotein B-100 is perturbed in the hepatoma-derived Huh7 cell. b Electron microscopy showed that the ApoB-crescent consists of an LD and a thin ER cistern (arrows) fusing each other. The $\mathrm{LD}$ of the ApoB-crescent is topologically equivalent to the lipid ester globule between the two membrane leaflets (see diagram in Fig. 5). c The structure shown in $\mathbf{a}$ and $\mathbf{b}$ probably represents the LD arrested at an intermediate stage of biogenesis, which is caused by tight binding of lipidated apolipoprotein B100 to the ER membrane
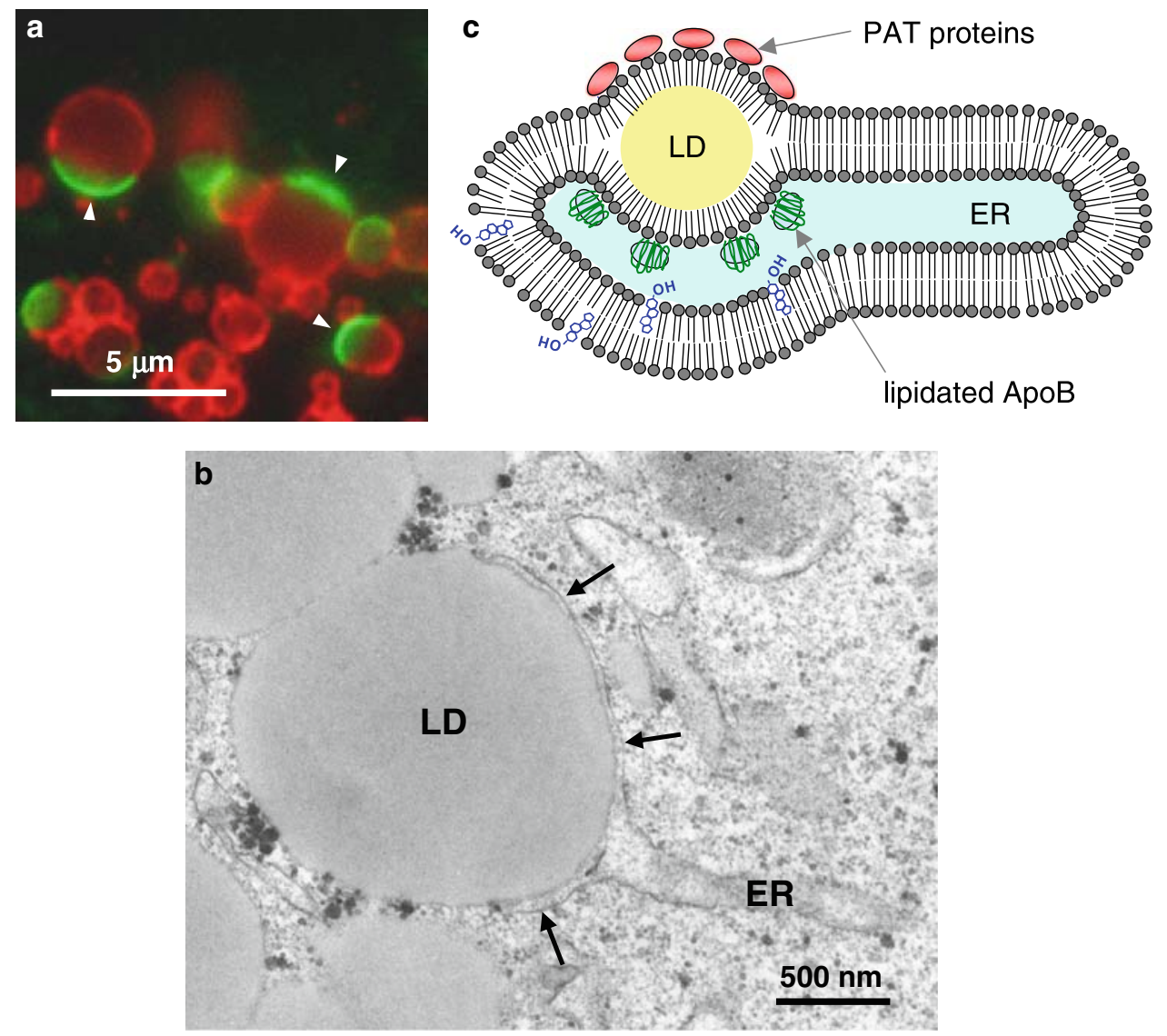

(Bostrom et al. 2005). The presence of SNARE proteins in the LD suggested that the fusion occurs by a mechanism similar to that of vesicular fusion (Bostrom et al. 2007), but the fusion between the LDs that are filled with lipid esters should give rise to an important difference from the fusion of vesicles enclosing the aqueous content. That is, in the vesicular fusion, the shape and volume of the fused vesicle can change in a flexible manner in accordance with the total membrane area. On the other hand, in the LD fusion, because the total volume of lipid esters appears to remain constant and the resultant LD regains the spherical shape immediately (Bostrom et al. 2005), the surface-to-volume ratio decreases, which then should cause surplus phospholipids (and proteins). Simple calculation says that, to make a large LD of $1 \mu \mathrm{m}$ in diameter only by fusion, 125 small LDs of $200 \mathrm{~nm}$ in diameter are needed for the lipid ester, but the surface of the large LD can be covered by the phospholipids derived from 25 small LDs, and that equivalent to 100 small LDs will become excess (Fig. 8a). If we start from LDs of $25 \mathrm{~nm}$ in diameter to make the $1 \mu \mathrm{m} \mathrm{LD}$, 64,000 LDs are required to collect sufficient lipid esters, and phospholipids from 62,400 LDs need to be processed in some way. There are several presuppositions for this calculation: the total volume and packing density of the lipid ester are the same, the lateral density of the surface phospholipid is the same, and so forth. Although they may not be valid always, it is likely that large surplus phospholipids and proteins should arise by LD fusion (Fig. 8a). The excess phospholipids and proteins may be simply released and utilized elsewhere; alternatively, they may be degraded by phospholipases (Marchesan et al. 2003), proteasomes (Xu et al. 2005), or other processes. There is also a possibility that the excess phospholipids and proteins may form some structures in or around the enlarged LD, which could explain the internal immunolabeling and membranous morphology in the core (Dvorak et al. 1992; Bozza et al. 1997; Robenek et al. 2004, 2005; Wan et al. 2007).

The existing LD may become larger by acquiring additional lipid esters by mechanisms other than mutual fusion. One possible way is the infusion of lipid esters via direct structural continuity between the ER and LD (Fig. 7b). The diagram on LD formation depicts that nascent LDs become independent, but whether the LD completely separated from the ER can exist has never been shown. The LD closely associated with the cytosolic surface of the ADRPenriched ER membrane was reported by immunoelectron microscopy (Robenek et al. 2006). The observed LD $>0.5 \mu \mathrm{m}$ in diameter, may be too large as a nascent one, but the result may suggest that the special ER domain is involved in the continuous ER-LD association. Alternatively, the ER and LD may undergo a cycle of fusion and fission for the lipid transfer (Fig. 7c). This mechanism was 


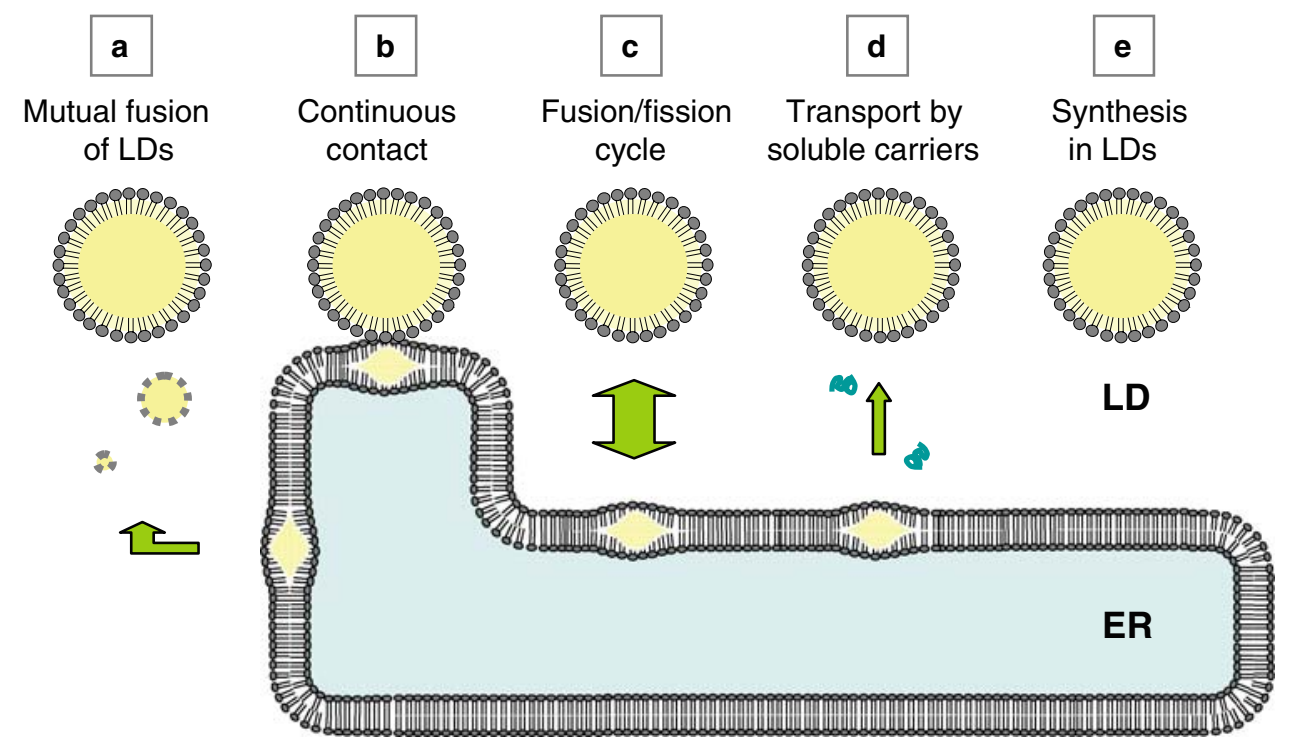

Fig. 7 Possible mechanisms of LD growth. The pre-existing LD may grow by accretion of the lipid ester by one or several of possible mechanisms. a The LD is shown to fuse with other LDs; for the net increase of the total lipid ester, nascent LDs, too small to be detected by conventional methods, may ferry the lipid ester to the pre-existing large LDs. b The LD may remain continuous to the mother ER membrane and thus obtain the additional lipid ester through the conduit. $\mathbf{c}$ The LD may be connected to the ER transiently, while the two organelles undergo a cycle of fusion and fission. $\mathbf{d}$ Soluble complexes may carry the lipid ester to the LD. e The lipid ester may be synthesized locally in the $\mathrm{LD}$
Fig. 8 The LD growth may cause changes in opposite directions. When the LD growth occurs solely by mutual fusion (a), a large surplus surface phospholipids and proteins should arise. This condition is likely to cause exchangeable proteins to leave the LD, whereas the constitutive proteins remain in the LD. The excess phospholipids and proteins might give rise to membranous structures in and/or out of the LD. On the contrary, when the LD grows by accretion of lipid esters in processes other than the mutual fusion (b), a deficiency of the surface phospholipids and proteins may occur, which may then recruit exchangeable proteins to the LD. Thus, the ratio of exchangeable and constitutive proteins in the LD could change to opposite directions depending on how the growth occurs

\section{a Growth by mutual fusion}
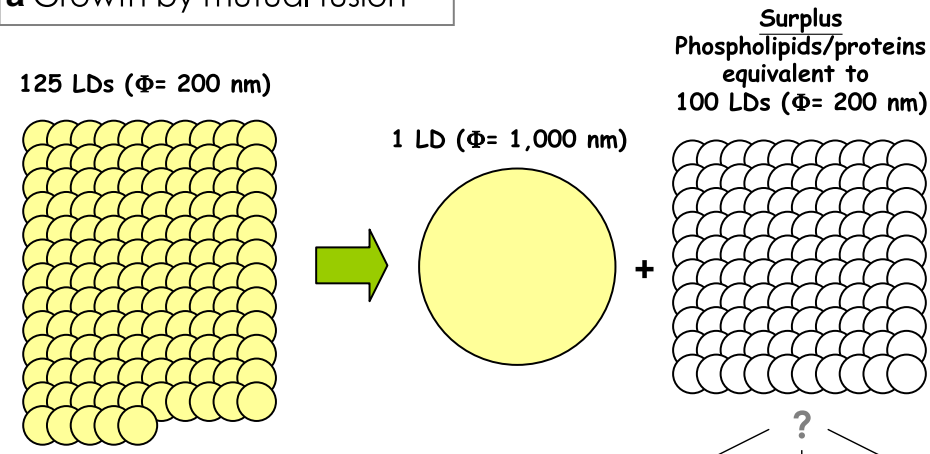

100 LDs $(\Phi=200 \mathrm{~nm})$
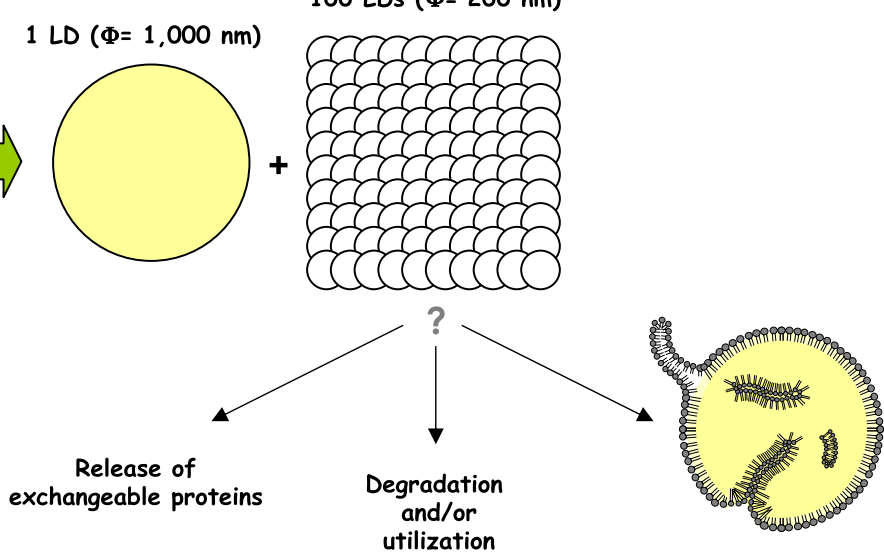

Foration of external/internal structures

b Growth by accretion of lipid esters

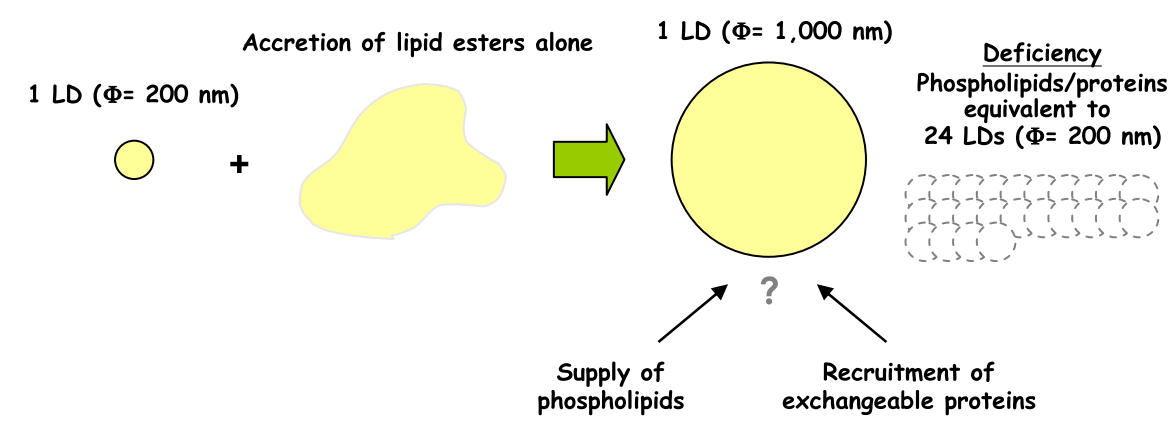



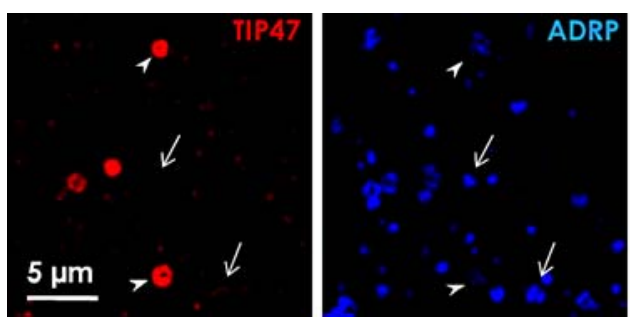

Fig. 9 Heterogeneity of LD-associated proteins in a cell. Huh7 cells were multiple-labeled by BODIPY493/503 (green) and by anti-TIP47 (red) and anti-ADRP (blue) antibodies. The LDs marked by BO-

proposed to occur in the hepatocyte to supply lipids from the LD to the ER for lipoprotein synthesis (Gibbons et al. 2000), but whether functional coupling/decoupling is accompanied with LD movements is not known. The supply of the lipid ester may also occur by a soluble complex using specific carrier proteins as shown in a transport from caveolae (Fig. 7d) (Uittenbogaard et al. 2002). Finally, the lipid ester may be synthesized locally by enzymes distributed to the LD (Fig. 7e). When LD growth occurs by one of these mechanisms, the corresponding amount of phospholipids and proteins needs to be supplied independently and exchangeable proteins may be recruited to rather than released from the LD (Fig. 8b).

The above conjecture suggests that changes of the surfaceto-volume ratio in the LD are likely to modify the composition of LD-associated proteins. Some proteins can exist both in LD-bound and soluble forms, for example, TIP47 and S312 , and they may be easily recruited to the LD when the available surface increases, whereas they may be released from the LD when the surface decreases. On the contrary, the proteins that can exist only in the $\mathrm{LD}$, for example, perilipin and ADRP, are unlikely to undergo drastic changes. The rapid recruitment of TIP47 upon oleic acid loading (Wolins et al. 2001; Ohsaki et al. 2006b) suggests that the LD growth in this condition may occur largely by non-fusion mechanisms. The heterogeneity of the LD-associated proteins in a cell (Fig. 9) (Moore et al. 2005; Wolins et al. 2005; Ohsaki et al. 2006b) may be generated as an LD goes through changes of the surface-to-volume ratio after its birth and the resulting difference in the protein composition should bring about the functional differences among the LDs.

Using several experimental systems, proteins facilitating LD formation have been reported. The readouts of the experiments are basically the total LD volume by microscopy and the lipid ester amount in the isolated LD fraction (Marchesan et al. 2003; Andersson et al. 2006; Magnusson et al. 2006). In view of technical limitations and possible multiple steps necessary for "visible" LD formation, it is not easy to specify where in the process a particular factor(s) is involved. It would be a future challenge to characterize which factors are necessary for which step of LD formation.

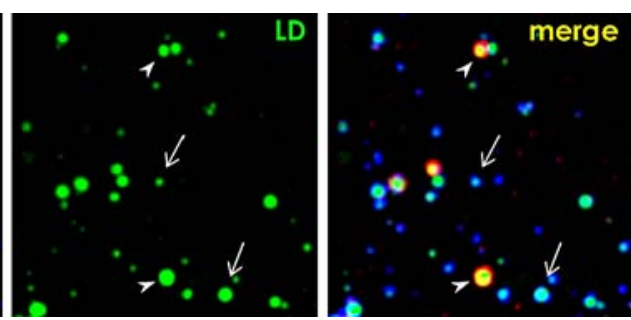

DIPY493/503 are mostly positive for ADRP alone (arrows), although the intensity of the ADRP labeling is varied among LDs. On the other hand, TIP47 is seen only in a limited population (arrowheads)

Involution of the LD

Involution of the LD occurs when the lipid ester is hydrolyzed by lipases. PAT proteins probably play a major role in the regulation of this event (Londos et al. 2005). In addition to the protective and docking functions as discussed above, phosphorylation of perilipin induces fragmentation of LDs in the adipocyte (Marcinkiewicz et al. 2006). This phenomenon should facilitate lipolysis because the surfaceto-volume ratio of the LD increases and the access of lipases to the lipid ester should be easier. Mechanical fragmentation of LDs that occurs upon cell homogenization should also induce exposure of the hydrophobic ester (Fujimoto and Ohsaki 2006).

\section{Motility of the LD}

The fusion and fission of the LD are inevitably accompanied by motility. The large LD in the adipocyte may not have much motility, but smaller LDs in non-adipocytes often show directional movements that occur along the microtubule mediated by dynein and it cofactor, dynactin (Welte et al. 1998; Targett-Adams et al. 2003; Bostrom et al. 2005). In the Drosophila embryo, the LD shows different patterns of movement in different stages, which is coordinated by an LD protein called Klar. A signaling protein Halo is thought to promote phosphorylation of lipid storage droplet-2 (LSD2), a perilipin homolog, in a developmentally regulated manner (Welte et al. 2005). The phosphorylated LSD2 then binds to Klar, and this interaction appears indispensable for coordination of LD motion (Welte et al. 2005). In this way, LSD2 may be the organizer that links LD motility and lipid homeostasis. It remains to be shown whether mammalian PAT proteins share the motility-related function.

\section{Functions of lipid droplets}

The canonical function of the LD is to store lipids as esters. Lipids stored in the LD are hydrolyzed and may be used for $\beta$-oxidation, membrane synthesis, protein modification, and 
generation of signaling molecules and other lipid products. A large amount of TG in the white adipocyte LD is used as the energy reserve of the whole body. CE in the steroidogenic cell LD is for steroid synthesis and arachidonic acid esters of the mast cell LD is for eicosanoid synthesis. In the hepatocyte, the lipid ester in the LD is utilized for lipoprotein formation, and, importantly, fatty acids generated by hydrolysis of the lipid ester are used for lipoprotein synthesis preferentially over those that are imported from the extracellular milieu or newly synthesized in the cell (Gibbons et al. 2000). This suggests that lipids derived from the LD may be channeled into specific metabolic pathways more efficiently than those from other sources.

The lipid storage itself is important for cellular defense. Excess free fatty acids (FAs) are toxic to cells ("lipotoxicity") and induction of cellular dysfunction and/or apoptosis have been reported in many cell types (Schaffer 2003). Unsaturated FAs can protect cells from the toxicity of saturated FAs in normal cells, whereas they are equally toxic in $\mathrm{Dgat}^{-/-}$fibroblasts (Listenberger et al. 2003). The protective function of unsaturated FAs can be explained by their ability to promote TG accumulation by functioning as ligands for peroxisome proliferator-acitivated receptor $\gamma$ and/or by serving as a favorable substrate for DGATs (Listenberger et al. 2003). The result shows that esterification of FAs and storage in the LD as inert esters are an important defense mechanism against lipotoxicity in non-adipocytes.

The above-mentioned functions are connected to the lipid trafficking, storage, and metabolism, and, altogether, they indicate that the LD is not a static organelle at all but a dynamic organelle that plays active roles in lipid homeostasis. Furthermore, recent studies indicated that the LD has functions that are not related to lipids directly. In the hepatocyte, lipidated apolipoprotein B-100 accumulates on the LD when the proteasomal or autophagic process is inhibited (Fig. 6a) (Fujimoto and Ohsaki 2006; Ohsaki et al. 2006a). The result suggested that the LD is a temporal storage site for lipidated ApoB to be degraded. Interestingly, $\alpha$-synuclein, a major protein of Lewy bodies found in the Parkinson's disease as well as other synucleinopathies, also has an affinity to the LD (Cole et al. 2002) and is degraded both by the proteasome and autophagy (Webb et al. 2003). Both apolipoprotein B-100 and $\alpha$-synuclein have hydrophobic segments (Giasson et al. 2001; Segrest et al. 2001) and are likely to form aggregates when left free in the aqueous environment. The LD may provide a surface that these proteins can bind through hydrophobic interactions, and thereby help disposal of the potentially toxic aggregate-prone proteins (Fujimoto and Ohsaki 2006). In a more physiological setting, a massive amount of histones are temporarily stored on the LD of the Drosophila embryo (Cermelli et al. 2006). In this case, the LD binding is likely to occur by electrostatic interactions, and histones are later released to exert their function in the nucleus. These results led to the hypothesis that the LD functions as a general sequestration site (Welte 2007), but the significance and the regulatory mechanisms may be diversified among proteins.

The isolated LD contains many proteins related to signaling and membrane trafficking (Brasaemle et al. 2004; Liu et al. 2004; Umlauf et al. 2004; Ozeki et al. 2005; Sato et al. 2006; Turro et al. 2006), and the result may imply the engagement of LDs in those activities. In fact, an in vitro experiment showed that Rab5, one of the many Rab proteins in the LD preparation, regulates the interaction between the LD and the early endosome (Liu et al. 2007). Considering potential artifacts that may arise during the LD isolation, the function of those proteins may need to be defined in the cellular context.

\section{Diseases related to lipid droplets}

Obesity, diabetes mellitus, and atherosclerosis are pandemic in many countries and effective prevention and treatment measures are urgently required from the social and economic standpoints. The LD can be an important target to cure these abnormalities, as exemplified by the reported association of polymorphisms at the perilipin locus (PLIN) and the risk of obesity in females of some ethnic groups (Tai and Ordovas 2007). The above association, however, was not found in other populations, suggesting the complexity behind obesity.

Diseases more directly related to the LD function are the neutral lipid storage disease and lipodystrophy. The neutral lipid storage disease is known as Chanarin-Dorfman syndrome (CDS), and it shows ichthyosis and heavy TG deposition in many tissues, though not in adipose tissue. CDS is caused by loss-of-function mutations of CGI-58 (Lefevre et al. 2001), and the function of CGI-58 as a strong activator of adipose triglyceride lipase (ATGL) appears to largely explain TG accumulation in non-adipocytes (Lass et al. 2006). The normal adiposity of the CDS patient is not readily understood by the above scheme, but the binding of perilipin A and CGI-58 in basal conditions and their separation upon $\beta$-adrenergic stimulation may be related to this enigmatic phenomenon (Subramanian et al. 2004). Lipodystrophy is the disorder characterized by the complete or partial lack of adipose tissue (Agarwal and Garg 2006). Human genetic lipodystrophy has been linked to several loci, including Berardinelli-Seip congenital lipodystrophy 2 (BSCL2) (Magre et al. 2001) and caveolin-1 (CAV1) (Kim et al. 2008). BSCL2 encodes seipin, and its yeast homolog, Fldlp, was shown to be important for the biogenesis and maintenance of the LD (Szymanski et al. 2007; Fei et al. 
2008). The result suggests that the mechanism of the LD formation is conserved in a wide range of species and critical for normal adipogenesis. However, the fact that patients deficient in BSCL2/seipin develop steatosis may suggest a critical difference in the LD formation mechanism among cells (Agarwal and Garg 2006).

The non-adipocyte LD is also a target of pathogens. Chlamydia trachomatis, a causative agent of trachoma and sexually transmitted diseases, induces accumulation of LDs around the intracellular vacuole where it inhabits, and it probably exploits the stored lipid for its growth (Kumar et al. 2006). Hepatitis C virus (HCV) appears to use the LD for proliferation (Miyanari et al. 2007). The single strand HCV RNA encodes three structural and seven non-structural proteins. Among these, a structural capsid protein (Core) (Barba et al. 1997) and a non-structural NS5A protein (Shi et al. 2002) are targeted to the LD when cDNAs encoding the proteins are transfected alone. The HCV particle assembles in the vicinity of the LD in cultured hepatoma cells, and deletion or mutations of Core to disturb its LD targeting suppressed HCV production (Boulant et al. 2007; Miyanari et al. 2007). The result indicates that the LD is critical for HCV reproduction, and the molecular linkage may be also related to the pathogenesis of hepatic steatosis caused by viral infection. The HCV infection is a world-wide health problem because it causes chronic hepatitis, liver cirrhosis, and hepatocellular carcinoma. The LD is becoming a target of active research from this perspective.

\section{Concluding remarks}

The presence of LD has been known for many years using classical lipid staining methods on histological sections, but it is only recently that the LD is regarded as an independent organelle. The LD plays a major role in lipid homeostasis, but is also engaged in functions that are seemingly unrelated to lipids. The unique architecture of the LD and the mechanism of its birth, growth, and modulation may be critical for all the activities. Given its importance related to various prevailing diseases, the LD poses many interesting questions to clinical researchers as well as basic biologists. With so many things to be studied, the next few years should find many new developments and surprises in this slippery sphere.

Acknowledgments Work in our laboratory has been supported by Grants-in-Aid for Scientific Research and the 21st Century COE Program "Integrated Molecular Medicine for Neuronal and Neoplastic Disorders" of the Ministry of Education, Culture, Sports, Science and Technology of the Government of Japan (to TF, YO, AF) and a grant from the Nitto Foundation (to YO).

\section{References}

Agarwal AK, Garg A (2006) Genetic disorders of adipose tissue development, differentiation, and death. Annu Rev Genomics Hum Genet 7:175-199

Andersson L, Bostrom P, Ericson J, Rutberg M, Magnusson B, Marchesan D, Ruiz M, Asp L, Huang P, Frohman MA, Boren J, Olofsson SO (2006) PLD1 and ERK2 regulate cytosolic lipid droplet formation. J Cell Sci 119:2246-2257

Angermuller S, Fahimi HD (1982) Imidazole-buffered osmium tetroxide: an excellent stain for visualization of lipids in transmission electron microscopy. Histochem J 14:823-835

Baba M, Osumi M, Ohsumi Y (1995) Analysis of the membrane structures involved in autophagy in yeast by freeze-replica method. Cell Struct Funct 20:465-471

Barba G, Harper F, Harada T, Kohara M, Goulinet S, Matsuura Y, Eder G, Schaff Z, Chapman MJ, Miyamura T, Brechot C (1997) Hepatitis $\mathrm{C}$ virus core protein shows a cytoplasmic localization and associates to cellular lipid storage droplets. Proc Natl Acad Sci USA 94:1200-1205

Bartz R, Li WH, Venables B, Zehmer JK, Roth MR, Welti R, Anderson RG, Liu P, Chapman KD (2007) Lipidomics reveals that adiposomes store ether lipids and mediate phospholipid traffic. J Lipid Res 48:837-847

Binns D, Januszewski T, Chen Y, Hill J, Markin VS, Zhao Y, Gilpin C, Chapman KD, Anderson RG, Goodman JM (2006) An intimate collaboration between peroxisomes and lipid bodies. J Cell Biol 173:719-731

Blanchette-Mackie EJ, Dwyer NK, Barber T, Coxey RA, Takeda T, Rondinone CM, Theodorakis JL, Greenberg AS, Londos C (1995) Perilipin is located on the surface layer of intracellular lipid droplets in adipocytes. J Lipid Res 36:1211-1226

Bostrom P, Rutberg M, Ericsson J, Holmdahl P, Andersson L, Frohman MA, Boren J, Olofsson SO (2005) Cytosolic lipid droplets increase in size by microtubule-dependent complex formation. Arterioscler Thromb Vasc Biol 25:1945-1951

Bostrom P, Andersson L, Rutberg M, Perman J, Lidberg U, Johansson BR, Fernandez-Rodriguez J, Ericson J, Nilsson T, Boren J, Olofsson SO (2007) SNARE proteins mediate fusion between cytosolic lipid droplets and are implicated in insulin sensitivity. Nat Cell Biol 9:1286-1293

Boulant S, Targett-Adams P, McLauchlan J (2007) Disrupting the association of hepatitis $C$ virus core protein with lipid droplets correlates with a loss in production of infectious virus. J Gen Virol 88:2204-2213

Bozza PT, Yu W, Penrose JF, Morgan ES, Dvorak AM, Weller PF (1997) Eosinophil lipid bodies: specific, inducible intracellular sites for enhanced eicosanoid formation. J Exp Med 186:909-920

Brasaemle DL (2007) Thematic review series: adipocyte biology. The perilipin family of structural lipid droplet proteins: stabilization of lipid droplets and control of lipolysis. J Lipid Res 48:2547-2559

Brasaemle DL, Barber T, Wolins NE, Serrero G, Blanchette-Mackie EJ, Londos C (1997) Adipose differentiation-related protein is an ubiquitously expressed lipid storage droplet-associated protein. J Lipid Res 38:2249-2263

Brasaemle DL, Dolios G, Shapiro L, Wang R (2004) Proteomic analysis of proteins associated with lipid droplets of basal and lipolytically stimulated 3T3-L1 adipocytes. J Biol Chem 279:46835-46842

Buhman KF, Accad M, Farese RV (2000) Mammalian acyl-CoA: cholesterol acyltransferases. Biochim Biophys Acta 1529:142-154

Bussell R Jr, Eliezer D (2003) A structural and functional role for 11mer repeats in alpha-synuclein and other exchangeable lipid binding proteins. J Mol Biol 329:763-778 
Carroll KS, Hanna J, Simon I, Krise J, Barbero P, Pfeffer SR (2001) Role of Rab9 GTPase in facilitating receptor recruitment by TIP47. Science 292:1373-1376

Cermelli S, Guo Y, Gross SP, Welte MA (2006) The lipid-droplet proteome reveals that droplets are a protein-storage depot. Curr Biol 16:1783-1795

Chang BH, Li L, Paul A, Taniguchi S, Nannegari V, Heird WC, Chan L (2006) Protection against fatty liver but normal adipogenesis in mice lacking adipose differentiation-related protein. Mol Cell Biol 26:1063-1076

Chang TY, Chang CC, Lin S, Yu C, Li BL, Miyazaki A (2001) Roles of acyl-coenzyme A: cholesterol acyltransferase-1 and -2. Curr Opin Lipidol 12:289-296

Cho SY, Shin ES, Park PJ, Shin DW, Chang HK, Kim D, Lee HH, Lee JH, Kim SH, Song MJ, Chang IS, Lee OS, Lee TR (2007) Identification of mouse Prp19p as a lipid droplet-associated protein and its possible involvement in the biogenesis of lipid droplets. J Biol Chem 282:2456-2465

Cole NB, Murphy DD, Grider T, Rueter S, Brasaemle D, Nussbaum RL (2002) Lipid droplet binding and oligomerization properties of the Parkinson's disease protein alpha-synuclein. J Biol Chem 277:6344-6352

Corda D, Colanzi A, Luini A (2006) The multiple activities of CtBP/ BARS proteins: the Golgi view. Trends Cell Biol 16:167-173

Dalen KT, Dahl T, Holter E, Arntsen B, Londos C, Sztalryd C, Nebb HI (2007) LSDP5 is a PAT protein specifically expressed in fatty acid oxidizing tissues. Biochim Biophys Acta 1771:210-227

Debarre D, Supatto W, Pena AM, Fabre A, Tordjmann T, Combettes L, Schanne-Klein MC, Beaurepaire E (2006) Imaging lipid bodies in cells and tissues using third-harmonic generation microscopy. Nat Methods 3:47-53

Drab M, Verkade P, Elger M, Kasper M, Lohn M, Lauterbach B, Menne J, Lindschau C, Mende F, Luft FC, Schedl A, Haller H, Kurzchalia TV (2001) Loss of caveolae, vascular dysfunction, and pulmonary defects in caveolin-1 gene-disrupted mice. Science 293:2449-2452

Ducharme NA, Bickel PE (2008) Lipid droplets in lipogenesis and lipolysis. Endocrinology 149:942-949

Dvorak AM, Morgan E, Schleimer RP, Ryeom SW, Lichtenstein LM, Weller PF (1992) Ultrastructural immunogold localization of prostaglandin endoperoxide synthase (cyclooxygenase) to nonmembrane-bound cytoplasmic lipid bodies in human lung mast cells, alveolar macrophages, type II pneumocytes, and neutrophils. J Histochem Cytochem 40:759-769

Dvorak AM, Morgan ES, Weller PF (2003) RNA is closely associated with human mast cell lipid bodies. Histol Histopathol 18:943-968

Fei W, Shui G, Gaeta B, Du X, Kuerschner L, Li P, Brown AJ, Wenk MR, Parton RG, Yang H (2008) Fld1p, a functional homologue of human seipin, regulates the size of lipid droplets in yeast. J Cell Biol 180:473-482

Fernandez MA, Albor C, Ingelmo-Torres M, Nixon SJ, Ferguson C, Kurzchalia T, Tebar F, Enrich C, Parton RG, Pol A (2006) Caveolin-1 is essential for liver regeneration. Science 313:1628-1632

Fra AM, Masserini M, Palestini P, Sonnino S, Simons K (1995) A photo-reactive derivative of ganglioside GM1 specifically cross-links VIP21-caveolin on the cell surface. FEBS Lett 375:11-14

Franke WW, Hergt M, Grund C (1987) Rearrangement of the vimentin cytoskeleton during adipose conversion: formation of an intermediate filament cage around lipid globules. Cell 49:131-141

Fujimoto T, Ohsaki Y (2006) Cytoplasmic lipid droplets: rediscovery of an old structure as a unique platform. Ann N Y Acad Sci 1086:104-115

Fujimoto T, Kogo H, Ishiguro K, Tauchi K, Nomura R (2001) Caveolin-2 is targeted to lipid droplets, a new "membrane domain" in the cell. J Cell Biol 152:1079-1085
Fujimoto Y, Itabe H, Sakai J, Makita M, Noda J, Mori M, Higashi Y, Kojima S, Takano T (2004) Identification of major proteins in the lipid droplet-enriched fraction isolated from the human hepatocyte cell line HuH7. Biochim Biophys Acta 1644:47-59

Fukumoto S, Fujimoto T (2002) Deformation of lipid droplets in fixed samples. Histochem Cell Biol 118:423-428

Garcia A, Sekowski A, Subramanian V, Brasaemle DL (2003) The central domain is required to target and anchor perilipin A to lipid droplets. J Biol Chem 278:625-635

Ghadially FN (1997) Ultrastructural pathology of the cell and matrix. Edward Arnold, London

Giasson BI, Murray IV, Trojanowski JQ, Lee VM (2001) A hydrophobic stretch of 12 amino acid residues in the middle of alpha-synuclein is essential for filament assembly. J Biol Chem 276:2380 2386

Gibbons GF, Islam K, Pease RJ (2000) Mobilisation of triacylglycerol stores. Biochim Biophys Acta 1483:37-57

Gocze PM, Freeman DA (1994) Factors underlying the variability of lipid droplet fluorescence in MA-10 Leydig tumor cells. Cytometry 17:151-158

Greenberg AS, Egan JJ, Wek SA, Garty NB, Blanchette-Mackie EJ, Londos C (1991) Perilipin, a major hormonally regulated adipocyte-specific phosphoprotein associated with the periphery of lipid storage droplets. J Biol Chem 266:11341-11346

Greenspan P, Mayer EP, Fowler SD (1985) Nile red: a selective fluorescent stain for intracellular lipid droplets. J Cell Biol 100:965973

Hakumaki JM, Kauppinen RA (2000) 1H NMR visible lipids in the life and death of cells. Trends Biochem Sci 25:357-362

Heid HW, Schnolzer M, Keenan TW (1996) Adipocyte differentiationrelated protein is secreted into milk as a constituent of milk lipid globule membrane. Biochem J 320:1025-1030

Hevonoja T, Pentikainen MO, Hyvonen MT, Kovanen PT, Ala-Korpela M (2000) Structure of low density lipoprotein (LDL) particles: basis for understanding molecular changes in modified LDL. Biochim Biophys Acta 1488:189-210

Hickenbottom SJ, Kimmel AR, Londos C, Hurley JH (2004) Structure of a lipid droplet protein; the PAT family member TIP47. Structure 12:1199-1207

Kaye GWC, Laby TH (1995) Tables of physical and chemical compounds, 16th edn. Longman Scientific and Technical, Essex

Kim CA, Delepine M, Boutet E, El Mourabit H, Le Lay S, Meier M, Nemani M, Bridel E, Leite CC, Bertola DR, Semple RK, O'Rahilly S, Dugail I, Capeau J, Lathrop M, Magre J (2008) Association of a homozygous nonsense caveolin-1 mutation with berardinelliseip congenital lipodystrophy. J Clin Endocrinol Metab 93:1129_ 1134

Kuerschner L, Moessinger C, Thiele C (2008) Imaging of lipid biosynthesis: how a neutral lipid enters lipid droplets. Traffic 9:338-352

Kumar Y, Cocchiaro J, Valdivia RH (2006) The obligate intracellular pathogen Chlamydia trachomatis targets host lipid droplets. Curr Biol 16:1646-1651

Lacey DJ, Beaudoin F, Dempsey CE, Shewry PR, Napier JA (1999) The accumulation of triacylglycerols within the endoplasmic reticulum of developing seeds of Helianthus annuus. Plant J 17:397-405

Lass A, Zimmermann R, Haemmerle G, Riederer M, Schoiswohl G, Schweiger M, Kienesberger P, Strauss JG, Gorkiewicz G, Zechner R (2006) Adipose triglyceride lipase-mediated lipolysis of cellular fat stores is activated by CGI-58 and defective in Chanarin-Dorfman Syndrome. Cell Metab 3:309-319

Le Lay S, Hajduch E, Lindsay MR, Le Liepvre X, Thiele C, Ferre P, Parton RG, Kurzchalia T, Simons K, Dugail I (2006) Cholesterolinduced caveolin targeting to lipid droplets in adipocytes: a role for caveolar endocytosis. Traffic 7:549-561 
Leber R, Zinser E, Zellnig G, Paltauf F, Daum G (1994) Characterization of lipid particles of the yeast, Saccharomyces cerevisiae. Yeast 10:1421-1428

Lefevre C, Jobard F, Caux F, Bouadjar B, Karaduman A, Heilig R, Lakhdar H, Wollenberg A, Verret JL, Weissenbach J, Ozguc M, Lathrop M, Prud'homme JF, Fischer J (2001) Mutations in CGI-58, the gene encoding a new protein of the esterase/lipase/thioesterase subfamily, in Chanarin-Dorfman syndrome. Am J Hum Genet 69:1002-1012

Lehner R, Kuksis A (1996) Biosynthesis of triacylglycerols. Prog Lipid Res 35:169-201

Listenberger LL, Han X, Lewis SE, Cases S, Farese RV Jr, Ory DS, Schaffer JE (2003) Triglyceride accumulation protects against fatty acid-induced lipotoxicity. Proc Natl Acad Sci USA 100:30773082

Listenberger LL, Ostermeyer-Fay AG, Goldberg EB, Brown WJ, Brown DA (2007) Adipocyte differentiation-related protein reduces the lipid droplet association of adipose triglyceride lipase and slows triacylglycerol turnover. J Lipid Res 48:2751-2761

Liu P, Ying Y, Zhao Y, Mundy DI, Zhu M, Anderson RG (2004) Chinese hamster ovary K2 cell lipid droplets appear to be metabolic organelles involved in membrane traffic. J Biol Chem 279:3787-3792

Liu P, Bartz R, Zehmer JK, Ying YS, Zhu M, Serrero G, Anderson RG (2007) Rab-regulated interaction of early endosomes with lipid droplets. Biochim Biophys Acta 1773:784-793

Londos C, Brasaemle DL, Schultz CJ, Segrest JP, Kimmel AR (1999) Perilipins, ADRP, and other proteins that associate with intracellular neutral lipid droplets in animal cells. Semin Cell Dev Biol 10:51-58

Londos C, Sztalryd C, Tansey JT, Kimmel AR (2005) Role of PAT proteins in lipid metabolism. Biochimie 87:45-49

Luckenbill LL, Cohen AS (1966) The association of lipid droplets with cytoplasmic filaments in avian subsynovial adipose cells. J Cell Biol 31:195-199

Magnusson B, Asp L, Bostrom P, Ruiz M, Stillemark-Billton P, Linden D, Boren J, Olofsson SO (2006) Adipocyte differentiation-related protein promotes fatty acid storage in cytosolic triglycerides and inhibits secretion of very low-density lipoproteins. Arterioscler Thromb Vasc Biol 26:1566-1571

Magre J, Delepine M, Khallouf E, Gedde-Dahl T Jr, Van Maldergem L, Sobel E, Papp J, Meier M, Megarbane A, Bachy A, Verloes A, d'Abronzo FH, Seemanova E, Assan R, Baudic N, Bourut C, Czernichow P, Huet F, Grigorescu F, de Kerdanet M, Lacombe D, Labrune P, Lanza M, Loret H, Matsuda F, Navarro J, NivelonChevalier A, Polak M, Robert JJ, Tric P, Tubiana-Rufi N, Vigouroux C, Weissenbach J, Savasta S, Maassen JA, Trygstad O, Bogalho P, Freitas P, Medina JL, Bonnicci F, Joffe BI, Loyson G, Panz VR, Raal FJ, O'Rahilly S, Stephenson T, Kahn CR, Lathrop M, Capeau J (2001) Identification of the gene altered in Berardinelli-Seip congenital lipodystrophy on chromosome 11q13. Nat Genet 28:365-370

Mahajan KN, Mitchell BS (2003) Role of human Pso4 in mammalian DNA repair and association with terminal deoxynucleotidyl transferase. Proc Natl Acad Sci USA 100:10746-10751

Marchesan D, Rutberg M, Andersson L, Asp L, Larsson T, Boren J, Johansson BR, Olofsson SO (2003) A phospholipase D-dependent process forms lipid droplets containing caveolin, adipocyte differentiation-related protein, and vimentin in a cell-free system. J Biol Chem 278:27293-27300

Marcinkiewicz A, Gauthier D, Garcia A, Brasaemle DL (2006) The phosphorylation of serine 492 of perilipin a directs lipid droplet fragmentation and dispersion. J Biol Chem 281:11901-11909

Martin S, Parton RG (2005) Caveolin, cholesterol, and lipid bodies. Semin Cell Dev Biol 16:163-174

Martin S, Parton RG (2006) Lipid droplets: a unified view of a dynamic organelle. Nat Rev Mol Cell Biol 7:373-378
Martin S, Driessen K, Nixon SJ, Zerial M, Parton RG (2005) Regulated localization of Rab18 to lipid droplets: effects of lipolytic stimulation and inhibition of lipid droplet catabolism. J Biol Chem 280:42325-42335

McGookey DJ, Anderson RG (1983) Morphological characterization of the cholesteryl ester cycle in cultured mouse macrophage foam cells. J Cell Biol 97:1156-1168

McMahon HT, Mills IG (2004) COP and clathrin-coated vesicle budding: different pathways, common approaches. Curr Opin Cell Biol 16:379-391

McManaman JL, Zabaronick W, Schaack J, Orlicky DJ (2003) Lipid droplet targeting domains of adipophilin. J Lipid Res 44:668-673

Miura S, Gan JW, Brzostowski J, Parisi MJ, Schultz CJ, Londos C, Oliver B, Kimmel AR (2002) Functional conservation for lipid storage droplet association among Perilipin, ADRP, and TIP47 (PAT)-related proteins in mammals, Drosophila, and Dictyostelium. J Biol Chem 277:32253-32257

Miyanari Y, Atsuzawa K, Usuda N, Watashi K, Hishiki T, Zayas M, Bartenschlager R, Wakita T, Hijikata M, Shimotohno K (2007) The lipid droplet is an important organelle for hepatitis $\mathrm{C}$ virus production. Nat Cell Biol 9:1089-1097

Moore HP, Silver RB, Mottillo EP, Bernlohr DA, Granneman JG (2005) Perilipin targets a novel pool of lipid droplets for lipolytic attack by hormone-sensitive lipase. J Biol Chem 280:4310943120

Mountford CE, Wright LC (1988) Organization of lipids in the plasma membranes of malignant and stimulated cells: a new model. Trends Biochem Sci 13:172-177

Murata M, Peranen J, Schreiner R, Wieland F, Kurzchalia TV, Simons K (1995) VIP21/caveolin is a cholesterol-binding protein. Proc Natl Acad Sci USA 92:10339-10343

Murphy DJ (2001) The biogenesis and functions of lipid bodies in animals, plants and microorganisms. Prog Lipid Res 40:325-438

Murphy DJ, Vance J (1999) Mechanisms of lipid-body formation. Trends Biochem Sci 24:109-115

Murphy G Jr, Rouse RL, Polk WW, Henk WG, Barker SA, Boudreaux MJ, Floyd ZE, Penn AL (2008) Combustion-derived hydrocarbons localize to lipid droplets in respiratory cells. Am J Respir Cell Mol Biol 38:532-540

Nagayama M, Uchida T, Gohara K (2007) Temporal and spatial variations of lipid droplets during adipocyte division and differentiation. J Lipid Res 48:9-18

Nakamura N, Fujimoto T (2003) Adipose differentiation-related protein has two independent domains for targeting to lipid droplets. Biochem Biophys Res Commun 306:333-338

Nan X, Potma EO, Xie XS (2006) Nonperturbative chemical imaging of organelle transport in living cells with coherent anti-stokes Raman scattering microscopy. Biophys J 91:728-735

Novikoff AB, Novikoff PM, Rosen OM, Rubin CS (1980) Organelle relationships in cultured 3T3-L1 preadipocytes. J Cell Biol 87:180-196

Ohsaki Y, Cheng J, Fujita A, Tokumoto T, Fujimoto T (2006a) Cytoplasmic lipid droplets are sites of convergence of proteasomal and autophagic degradation of apolipoprotein B. Mol Biol Cell 17:2674-2683

Ohsaki Y, Maeda T, Maeda M, Tauchi-Sato K, Fujimoto T (2006b) Recruitment of TIP47 to lipid droplets is controlled by the putative hydrophobic cleft. Biochem Biophys Res Commun 347:279287

Ohsaki Y, Cheng J, Suzuki T, Fujita A, Fujimoto T (2008) Lipid droplets are arrested in the ER membrane by tight binding of lipidated apolipoprotein B-100. in press, J Cell Sci

Ostermeyer AG, Paci JM, Zeng Y, Lublin DM, Munro S, Brown DA (2001) Accumulation of caveolin in the endoplasmic reticulum redirects the protein to lipid storage droplets. J Cell Biol 152:1071-1078 
Ostermeyer AG, Ramcharan LT, Zeng Y, Lublin DM, Brown DA (2004) Role of the hydrophobic domain in targeting caveolin-1 to lipid droplets. J Cell Biol 164:69-78

Ozeki S, Cheng J, Tauchi-Sato K, Hatano N, Taniguchi H, Fujimoto T (2005) Rab18 localizes to lipid droplets and induces their close apposition to the endoplasmic reticulum-derived membrane. J Cell Sci 118:2601-2611

Ploegh HL (2007) A lipid-based model for the creation of an escape hatch from the endoplasmic reticulum. Nature 448:435-438

Pol A, Luetterforst R, Lindsay M, Heino S, Ikonen E, Parton RG (2001) A caveolin dominant negative mutant associates with lipid bodies and induces intracellular cholesterol imbalance. J Cell Biol 152:1057-1070

Praefcke GJ, McMahon HT (2004) The dynamin superfamily: universal membrane tubulation and fission molecules? Nat Rev Mol Cell Biol 5:133-147

Prattes S, Horl G, Hammer A, Blaschitz A, Graier WF, Sattler W, Zechner R, Steyrer E (2000) Intracellular distribution and mobilization of unesterified cholesterol in adipocytes: triglyceride droplets are surrounded by cholesterol-rich ER-like surface layer structures. J Cell Sci 113:2977-2989

Puri V, Konda S, Ranjit S, Aouadi M, Chawla A, Chouinard M, Chakladar A, Czech MP (2007) Fat-specific protein 27, a novel lipid droplet protein that enhances triglyceride storage. J Biol Chem 282:34213-34218

Ramsammy LS, Brockerhoff H (1982) Lysophosphatidylcholinecholesterol complex. J Biol Chem 257:3570-3574

Razani B, Combs TP, Wang XB, Frank PG, Park DS, Russell RG, Li M, Tang B, Jelicks LA, Scherer PE, Lisanti MP (2002) Caveolin1-deficient mice are lean, resistant to diet-induced obesity, and show hypertriglyceridemia with adipocyte abnormalities. J Biol Chem 277:8635-8647

Riemersma JC (1968) Osmium tetroxide fixation of lipids for electron microscopy. A possible reaction mechanism. Biochim Biophys Acta 152:718-727

Robenek MJ, Severs NJ, Schlattmann K, Plenz G, Zimmer KP, Troyer D, Robenek H (2004) Lipids partition caveolin-1 from ER membranes into lipid droplets: updating the model of lipid droplet biogenesis. FASEB J 18:866-868

Robenek H, Robenek MJ, Troyer D (2005) PAT family proteins pervade lipid droplet cores. J Lipid Res 46:1331-1338

Robenek H, Hofnagel O, Buers I, Robenek MJ, Troyer D, Severs NJ (2006) Adipophilin-enriched domains in the ER membrane are sites of lipid droplet biogenesis. J Cell Sci 119:4215-4224

Sato S, Fukasawa M, Yamakawa Y, Natsume T, Suzuki T, Shoji I, Aizaki H, Miyamura T, Nishijima M (2006) Proteomic profiling of lipid droplet proteins in hepatoma cell lines expressing hepatitis $\mathrm{C}$ virus core protein. J Biochem 139:921-930

Schaffer JE (2003) Lipotoxicity: when tissues overeat. Curr Opin Lipidol 14:281-287

Schrader M (2001) Tubulo-reticular clusters of peroxisomes in living COS-7 cells: dynamic behavior and association with lipid droplets. J Histochem Cytochem 49:1421-1429

Segrest JP, Jones MK, De Loof H, Dashti N (2001) Structure of apolipoprotein B-100 in low density lipoproteins. J Lipid Res 42:1346-1367

Sharma DK, Brown JC, Choudhury A, Peterson TE, Holicky E, Marks DL, Simari R, Parton RG, Pagano RE (2004) Selective stimulation of caveolar endocytosis by glycosphingolipids and cholesterol. Mol Biol Cell 15:3114-3122

Shi ST, Polyak SJ, Tu H, Taylor DR, Gretch DR, Lai MM (2002) Hepatitis C virus NS5A colocalizes with the core protein on lipid droplets and interacts with apolipoproteins. Virology 292:198210

Smith SJ, Cases S, Jensen DR, Chen HC, Sande E, Tow B, Sanan DA, Raber J, Eckel RH, Farese RV Jr (2000) Obesity resistance and multiple mechanisms of triglyceride synthesis in mice lacking Dgat. Nat Genet 25:87-90

Sorger D, Daum G (2002) Synthesis of triacylglycerols by the acylcoenzyme A: diacyl-glycerol acyltransferase Dgalp in lipid particles of the yeast Saccharomyces cerevisiae. J Bacteriol 184:519-524

Stemberger BH, Walsh RM, Patton S (1984) Morphometric evaluation of lipid droplet associations with secretory vesicles, mitochondria and other components in the lactating cell. Cell Tissue Res 236:471-475

Stone SJ, Levin MC, Farese RV Jr (2006) Membrane topology and identification of key functional amino acid residues of murine acyl-CoA: diacylglycerol acyltransferase-2. J Biol Chem 281:40273-40282

Subramanian V, Rothenberg A, Gomez C, Cohen AW, Garcia A, Bhattacharyya S, Shapiro L, Dolios G, Wang R, Lisanti MP, Brasaemle DL (2004) Perilipin A mediates the reversible binding of CGI-58 to lipid droplets in 3T3-L1 adipocytes. J Biol Chem 279:42062-42071

Sztalryd C, Xu G, Dorward H, Tansey JT, Contreras JA, Kimmel AR, Londos C (2003) Perilipin A is essential for the translocation of hormone-sensitive lipase during lipolytic activation. J Cell Biol 161:1093-1103

Sztalryd C, Bell M, Lu X, Mertz P, Hickenbottom S, Chang BH, Chan L, Kimmel AR, Londos C (2006) Functional compensation for adipose differentiation-related protein (ADFP) by Tip47 in an ADFP null embryonic cell line. J Biol Chem 281:3434134348

Szymanski KM, Binns D, Bartz R, Grishin NV, Li WP, Agarwal AK, Garg A, Anderson RG, Goodman JM (2007) The lipodystrophy protein seipin is found at endoplasmic reticulum lipid droplet junctions and is important for droplet morphology. Proc Natl Acad Sci USA 104:20890-20895

Tai ES, Ordovas JM (2007) The role of perilipin in human obesity and insulin resistance. Curr Opin Lipidol 18:152-156

Tansey JT, Sztalryd C, Gruia-Gray J, Roush DL, Zee JV, Gavrilova O, Reitman ML, Deng CX, Li C, Kimmel AR, Londos C (2001) Perilipin ablation results in a lean mouse with aberrant adipocyte lipolysis, enhanced leptin production, and resistance to diet-induced obesity. Proc Natl Acad Sci USA 98:6494-6499

Targett-Adams P, Chambers D, Gledhill S, Hope RG, Coy JF, Girod A, McLauchlan J (2003) Live cell analysis and targeting of the lipid droplet-binding adipocyte differentiation-related protein. J Biol Chem 278:15998-16007

Tauchi-Sato K, Ozeki S, Houjou T, Taguchi R, Fujimoto T (2002) The surface of lipid droplets is a phospholipid monolayer with a unique fatty acid composition. J Biol Chem 277:44507-44512

Trigatti BL, Anderson RG, Gerber GE (1999) Identification of caveolin-1 as a fatty acid binding protein. Biochem Biophys Res Commun 255:34-39

Turro S, Ingelmo-Torres M, Estanyol JM, Tebar F, Fernandez MA, Albor CV, Gaus K, Grewal T, Enrich C, Pol A (2006) Identification and characterization of associated with lipid droplet protein 1: a novel membrane-associated protein that resides on hepatic lipid droplets. Traffic 7:1254-1269

Uittenbogaard A, Everson WV, Matveev SV, Smart EJ (2002) Cholesteryl ester is transported from caveolae to internal membranes as part of a caveolin-annexin II lipid-protein complex. J Biol Chem 277:4925-4931

Umlauf E, Csaszar E, Moertelmaier M, Schuetz GJ, Parton RG, Prohaska R (2004) Association of stomatin with lipid bodies. J Biol Chem 279:23699-23709

van Manen HJ, Kraan YM, Roos D, Otto C (2005) Single-cell Raman and fluorescence microscopy reveal the association of lipid bodies with phagosomes in leukocytes. Proc Natl Acad Sci USA 102:10159-10164 
Waltermann M, Steinbuchel A (2005) Neutral lipid bodies in prokaryotes: recent insights into structure, formation, and relationship to eukaryotic lipid depots. J Bacteriol 187:3607-3619

Waltermann M, Hinz A, Robenek H, Troyer D, Reichelt R, Malkus U, Galla HJ, Kalscheuer R, Stoveken T, von Landenberg P, Steinbuchel A (2005) Mechanism of lipid-body formation in prokaryotes: how bacteria fatten up. Mol Microbiol 55:750-763

Wan HC, Melo RC, Jin Z, Dvorak AM, Weller PF (2007) Roles and origins of leukocyte lipid bodies: proteomic and ultrastructural studies. FASEB J 21:167-178

Wanner G, Theimer RR (1978) Membranous appendices of spherosomes (oleosomes): possible role in fat utilization in germinating oil seeds. Planta 140:163-169

Wanner G, Formanek H, Theimer RR (1981) The ontogeny of lipid bodies (spherosomes) in plant cells: ultrastructural evidence. Planta 151:109-123

Webb JL, Ravikumar B, Atkins J, Skepper JN, Rubinsztein DC (2003) Alpha-Synuclein is degraded by both autophagy and the proteasome. J Biol Chem 278:25009-25013

Welte MA (2007) Proteins under new management: lipid droplets deliver. Trends Cell Biol 17:363-369

Welte MA, Gross SP, Postner M, Block SM, Wieschaus EF (1998) Developmental regulation of vesicle transport in Drosophila embryos: forces and kinetics. Cell 92:547-557

Welte MA, Cermelli S, Griner J, Viera A, Guo Y, Kim DH, Gindhart JG, Gross SP (2005) Regulation of lipid-droplet transport by the perilipin homolog LSD2. Curr Biol 15:1266-1275

Whitehead JP, Simpson F, Hill MM, Thomas EC, Connolly LM, Collart F, Simpson RJ, James DE (2004) Insulin and oleate promote translocation of inosine- $5^{\prime}$ monophosphate dehydrogenase to lipid bodies. Traffic 5:739-749
Wolins NE, Rubin B, Brasaemle DL (2001) TIP47 associates with lipid droplets. J Biol Chem 276:5101-5108

Wolins NE, Quaynor BK, Skinner JR, Schoenfish MJ, Tzekov A, Bickel PE (2005) S3-12, Adipophilin, and TIP47 package lipid in adipocytes. J Biol Chem 280:19146-19155

Wolins NE, Brasaemle DL, Bickel PE (2006a) A proposed model of fat packaging by exchangeable lipid droplet proteins. FEBS Lett 580:5484-5491

Wolins NE, Quaynor BK, Skinner JR, Tzekov A, Croce MA, Gropler MC, Varma V, Yao-Borengasser A, Rasouli N, Kern PA, Finck BN, Bickel PE (2006b) OXPAT/PAT-1 is a PPAR-induced lipid droplet protein that promotes fatty acid utilization. Diabetes 55:3418-3428

Xu G, Sztalryd C, Lu X, Tansey JT, Gan J, Dorward H, Kimmel AR, Londos C (2005) Post-translational regulation of adipose differentiation-related protein by the ubiquitin/proteasome pathway. J Biol Chem 280:42841-42847

Yamaguchi T, Omatsu N, Matsushita S, Osumi T (2004) CGI-58 interacts with perilipin and is localized to lipid droplets. Possible involvement of CGI-58 mislocalization in Chanarin-Dorfman syndrome. J Biol Chem 279:30490-30497

Yamaguchi T, Matsushita S, Motojima K, Hirose F, Osumi T (2006) MLDP, a novel PAT family protein localized to lipid droplets and enriched in the heart, is regulated by peroxisome proliferator-activated receptor alpha. J Biol Chem 281:14232-14240

Yu W, Cassara J, Weller PF (2000) Phosphatidylinositide 3-kinase localizes to cytoplasmic lipid bodies in human polymorphonuclear leukocytes and other myeloid-derived cells. Blood 95:10781085

Zweytick D, Athenstaedt K, Daum G (2000) Intracellular lipid particles of eukaryotic cells. Biochim Biophys Acta 1469:101-120 